University of Nebraska - Lincoln

DigitalCommons@University of Nebraska - Lincoln

\title{
ASSESSING APPLICATION UNIFORMITY OF A VARIABLE RATE IRRIGATION SYSTEM IN A WINDY LOCATION
}

\author{
Susan A. O'Shaughnessy \\ USDA-ARS, Susan.OShaughnessy@ars.usda.gov \\ Yenny F. Urrego \\ USDA-ARS \\ Steven R. Evett \\ USDA-ARS, steve.evett@ars.usda.gov \\ Paul D. Colaizzi \\ USDA-ARS, Paul.Colaizzi@ARS.USDA.GOV \\ Terry A. Howell \\ USDA-ARS, Terry.Howell@ars.usda.gov
}

Follow this and additional works at: https://digitalcommons.unl.edu/usdaarsfacpub

\begin{abstract}
O'Shaughnessy, Susan A.; Urrego, Yenny F.; Evett, Steven R.; Colaizzi, Paul D.; and Howell, Terry A., "ASSESSING APPLICATION UNIFORMITY OF A VARIABLE RATE IRRIGATION SYSTEM IN A WINDY LOCATION" (2013). Publications from USDA-ARS / UNL Faculty. 1836.

https://digitalcommons.unl.edu/usdaarsfacpub/1836
\end{abstract}

This Article is brought to you for free and open access by the U.S. Department of Agriculture: Agricultural Research Service, Lincoln, Nebraska at DigitalCommons@University of Nebraska - Lincoln. It has been accepted for inclusion in Publications from USDA-ARS / UNL Faculty by an authorized administrator of DigitalCommons@University of Nebraska - Lincoln. 


\title{
ASSESSING APPLICATION UNIFORMITY OF A VARIABLE RATE IRRIGATION SYSTEM IN A WINDY LOCATION
}

\author{
S. A. O’Shaughnessy, Y. F. Urrego, S. R. Evett, P. D. Colaizzi, T. A. Howell
}

\begin{abstract}
Variable rate irrigation (VRI) systems are commercially available and can easily be retrofitted onto moving sprinkler systems. However, there are few reports on the application performance of such equipment. In this study, application uniformity of two center pivots equipped with a commercial VRI system were tested using fixed-plate sprinklers and a range of irrigation rates $(100 \%, 80 \%, 70 \%, 50 \%$, and $30 \%)$. Catch cans were arranged in transect, arcwise, and grid patterns to test the accuracy of application depth, and the uniformity of application in the direction of pivot travel and to investigate changes in uniformity along the pivot lateral between irrigation zones. The mean Heermann and Hein coefficient of uniformity $\left(C U_{H H}\right)$ and the mean lower-quarter distribution uniformity $\left(D U_{l q}\right)$ in the direction of pivot travel and along the pivot lateral were approximately $88 \%$ and $80 \%$, respectively. Application uniformity was impacted at the border of adjacent irrigation zones along the pivot lateral when zones were applying different irrigation depths. While wind speed and direction did not appreciably decrease uniformity of application, it did impact absolute catch measurements. The mean evaporation and drift loss for all trials was $9.3 \%$, and ranged from $1 \%$ to $19 \%$. Applying variable rate irrigation significantly impacted uniformity of application for a distance $3 \mathrm{~m}$ wide between irrigation zones of different irrigation depths in spans 1-3 of the three-span, and a distance 6 to $9 \mathrm{~m}$ wide between irrigation zones in spans 5 and 6 of the six-span center pivot. Overall, the uniformity of application in the direction of pivot travel and within each irrigation zone was similar to values reported for other VRI sprinkler systems. The root mean square error between the prescribed and actual applied depth was $<3.0 \mathrm{~mm}$ for catch collected in all spans along the pivot lateral and in the direction of pivot travel. This indicates that this commercial VRI is well suited for site-specific irrigation management. However, uniformity of application could be affected by the width of the irrigation management zones as well as sprinkler design and environmental factors.
\end{abstract}

Keywords. Application uniformity, Low-quarter distribution, Catch cans, Coefficient of uniformity, Pulse on/off, Variable rate irrigation.

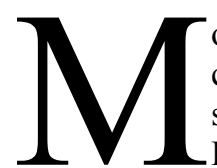
oving sprinkler irrigation systems now constitute over $84 \%$ of pressurized irrigation systems in the United States (USDA, 2009). Due to increasing competition for quality water and demand for food, fiber, and fuel, the efficient use of sprinkler irrigation systems is a critical goal for production agriculture. Variable rate irrigation systems have an opportunity to improve water productivity by

Submitted for review in September 2012 as manuscript number SW 9931 approved for publication by the Soil \& Water Division of ASABE in May 2013.

The use of trade, firm, or corporation names in this article is for the information and convenience of the reader. Such use does not constitute an official endorsement or approval by the United States Department of Agriculture or the Agricultural Research Service of any product or service to the exclusion of others that may be suitable. The USDA is an equal opportunity provider and employer.

The authors are Susan A. O'Shaughnessy, ASABE Member, Research Agricultural Engineer, Steven R. Evett, ASABE Member, Research Soil Scientist, Yenny Urrego, Ph.D. Candidate, EEAD-CSIC Estación Experimental Aula Dei 50059 Zaragoza, Spain, Paul D. Colaizzi, Research Agricultural Engineer, and Terry A. Howell, Sr., ASABE Member, Laboratory Director, USDA-ARS Bushland, Texas Corresponding author: Susan Ann O'Shaughnessy, P.O. Drawer 10, Bushland, TX 79012; phone: 806-356-5770; e-mail: susan.oshaughnessy@ars.usda.gov. precise delivery of accurate irrigation amounts, thus avoiding under or over irrigation. Crop water needs can vary due to within-field differences in soil texture, topography, and biotic stresses. With the use of site-specific irrigation equipment or VRI systems, it is possible to apply variable amounts of irrigation along the irrigation lateral and in the direction of travel to meet site-specific crop water needs. There are different methodologies available to deliver varying irrigation amounts along a lateral. One approach is to use parallel sprinkler control (McCann et al., 1997; King and Wall, 1998; King et al., 1999) or multiple manifolds; each valved separately (Sadler et al., 1996; Omary et al., 1997, Stone et al., 2006). Another is to regulate the flow of water through each sprinkler drop hose by controlling the "on/off" cycle of a hydraulic valve positioned above the drop hose (Evans et al., 1996; Dukes and Perry; 2006; Han et al., 2009; Chavez et al., 2010). A third design is to change the cross-sectional area of a sprinkler nozzle by cycling a retractable pin in and out of the nozzle in a controlled manner (King and Kincaid, 2004). Assessing the accuracy of the prescribed depth of irrigation is critical for the implementation of site-specific irrigation systems. To evaluate the application uniformity of moving sprinkler irrigation systems, it is common to use 
catch can testing and guidelines under ASABE Standard S436.1 (ASABE Standards, 2007).

It is also worthwhile to identify the amount of variability or changes in uniformity of application imposed by irrigating with a VRI system so as to realize its practical limitations. Due to sprinkler types and spacing, operating pressure, and wind characteristics, there is a discrete length along the lateral between two zones operating at different application rates within which the application rate is variable and not representative of that intended for either zone. By quantifying the length of this variability along the pivot lateral when operating irrigation zones at different rates, the minimum width of a management zone for precision application can be identified. This is important because overlap spray from adjacent zones may significantly influence the prescribed irrigation amount of too narrow a management zone. Similarly, the minimum center pivot sector size for variable crop water stress, whether from abiotic or biotic sources, can be established by characterizing arc-wise changes in uniformity of application. Prior to using sprinkler irrigation equipment, it is prudent to assess its uniformity of application and eliminate any problems before the start of an irrigation season. Just as in the case of non-VRI sprinkler systems, application uniformity of VRI systems can be impacted by climatic conditions, type of sprinkler hardware, sprinkler spacing, the condition of the irrigation system components, system operating pressure (Clark et al., 2003; Zhang et al., 2011), and sprinkler height above the ground (Ortiz et al., 2009). Mean depth and uniformity can also be affected by the equipment used to make the assessment, such as the type of collector (Kohl, 1972; Marek et al., 1985) and the height of the collector above the ground (Dogan et al., 2008). However, the uniformity of application for a center pivot system appears to be relatively insensitive to collection spacing (Rogers et al., 2009).

While documentation on application uniformity measurements for variable rate irrigation systems is limited, published assessments are favorable. Dukes and Perry (2006) performed variable rate uniformity tests on spans 3 and 4 of a four-span center pivot system using irrigation rates of $20 \%, 50 \%, 80 \%$, and $100 \%$ for application depths of $2,4,7$, and $9 \mathrm{~mm}$, respectively; and on a linear-move system using irrigation rates of $25 \%, 50 \%, 75 \%$, and $100 \%$ for application depths of $6,11,16$, and $20 \mathrm{~mm}$, respectively. The center pivot had flexible drop hoses spaced $5.1 \mathrm{~m}$ apart with moving spray plate sprinklers and pressure regulators rated at $67 \mathrm{kPa}$. The linear-move sprinkler system was outfitted with fixed and moving spray plate sprinklers, spaced $2.3 \mathrm{~m}$ and $3 \mathrm{~m}$ apart, respectively, on each of three spans. Both systems were designed with solenoid valves to pulse water "on/off" to apply variable irrigation rates. Overall, the coefficient of uniformity and $\mathrm{DU}_{\mathrm{lq}}$ averaged $93 \%$ and $90 \%$, respectively, for the center pivot system, and $84 \%$ and $74 \%$ for the linear-move system. Wind conditions were $<5 \mathrm{~m} \mathrm{~s}^{-1}$ when both systems were tested. Han et al. (2009) reported that the pulsing technique of their VRI system for a linear-move system produced coefficient of uniformity values of $94 \%, 95 \%$, $92 \%$, and $80 \%$ for application depths of $25,19,13$, and
$6 \mathrm{~mm}$, respectively, with an average application error of less than $2 \%$. Stone et al. (2006) quantified the precision of the application rate of a center pivot modified with distributed manifolds and programmable logic controller to deliver varying rates of irrigation along the pivot lateral by comparing designed to measured flows. When the manifolds were used in combination, they produced application depths near the design depths.

Studies in which accuracy of application of depth are reported include work by McCann et al.(1997), using 10 catch cans spaced $1 \mathrm{~m}$ apart in four alternating rows of 2 and 3 cans located in the center of each irrigation plot which was $83 \mathrm{~m}^{2}$ for initial trials and increased to $330 \mathrm{~m}^{2}$ to reduce boundary effects due to overlapping spray of different irrigation zones. Chavez et al. (2010) arranged catch cans in a $1.5 \times 1.5 \mathrm{~m}$ grid to assess application depth for a linear move system which was modified at Washington State University to provide for variable rate irrigation.

Sustained wind speeds in the Texas High Plains region are above the recommended maximum for performing catch can tests (ASABE Standards, 2007), and therefore it is important to determine its influence on application uniformity testing. Seginer and Kostrinsky (1975) reported that significant wind speeds increased loss of water between the sprinkler and collectors. Ortiz et al. (2009) determined that mean evaporation and drift loss (EDL) were $9.2 \%$ and $13.6 \%$ for fixed spray plate sprinklers 1 and $2.5 \mathrm{~m}$ above the ground for daytime catch can trials performed in average wind speeds of 1.4 and $6.2 \mathrm{~m} \mathrm{~s}^{-1}$. Under windy conditions, application uniformity and distribution of irrigation could also be significantly affected, decreasing measured values of $\mathrm{CU}_{\mathrm{HH}}$ and $\mathrm{DU}_{\mathrm{lq}}$ (Seginer et al., 1991; Kincaid et al., 1996; Tarjuelo et al., 1999; Playan et al., 2006).

Speed is not the only characteristic of wind that affects sprinkler application uniformity; wind direction confounds uniformity coefficients and application depth. Wind direction can positively or negatively impact measured uniformity of application by causing water droplets to drift in different directions, increasing or reducing the collected water in catch cans. Steiner et al. (1983) reported evaporation and drift losses (EDL) in three different areas along the length of a three-span pivot (400 $\mathrm{m}$ length) were similar when the wind was blowing towards the pivot lateral at an angle that was nearly parallel to the lateral even though climatic conditions were different during catch can trials. In this case, EDL varied from $14.4 \%$ to $17.5 \%$ of applied water. However, when the wind direction was nearly perpendicular to the pivot lateral, EDL measured in the same locations ranged from $0.8 \%$ to $22.5 \%$ of applied water, indicating that wind direction affected EDL.

Quantifying the uniformity of irrigation depth applied within an irrigation management zone along the moving lateral and determining the resolution of control in an arcwise direction is key to assessing VRI site-specific capabilities for producers and for interpreting experimental results. The goals of this study were to evaluate the accuracy of irrigation delivery and assess the application uniformity of newly installed VRI hardware on a three- and 
six-span center pivot system. Specific objectives were to assess the uniformity of application within different spans and irrigation zones along the pivot laterals; quantify the variation or change of $\mathrm{CU}_{\mathrm{HH}}$ or $\mathrm{DU}_{\mathrm{lq}}$ imposed between sprinkler zones of different irrigation rates along the pivot lateral and in the direction of pivot travel when the irrigation rate was changed; and characterize the effects of wind speed and direction on application uniformity while operating the VRI system.

\section{MATERIALS AND MethodS}

\section{EXPERIMENTAL SITE AND EXISTING IRRIGATION SYSTEM}

Experiments took place at the Conservation and Production Research Laboratory, Bushland, Texas (35 ${ }^{\circ} 11^{\text {' }}$ $\mathrm{N}, 102^{\circ} 06^{\prime} \mathrm{W}, 1170 \mathrm{~m}$ above mean sea level). Catch can trials were performed in April-June 2011 and in MarchMay 2012 using two center pivot irrigation systems, one a three-span and the other a six-span system. The lateral lengths were $131 \mathrm{~m}$ (three-span) and $260 \mathrm{~m}$ (six-span), which irrigated field surfaces of 5.4 and 21.4 ha, respectively, and were equipped with drop hoses spaced $1.52 \mathrm{~m}$ apart. The trials were conducted during daylight hours. Meteorological data were collected from nearby weather stations located less than $30 \mathrm{~m}$ from each field (Evett et al., 2011) and wind speed data were from $2 \mathrm{~m}$ elevation anemometers.

\section{VARIABLE RATE IRRIGATION EQUIPMENT}

The existing three-span and six-span irrigation systems with Pro 2 control panels were retrofitted with a VRI system, which was commercially available from Valmont Industries Inc. (Valley, Neb.). The VRI system was comprised of software to create a variable rate irrigation prescription and hardware components. The main hardware devices were a programmable logic controller (PLC), a global positioning system (GPS) receiver, electronic solenoid valves for sprinkler bank control, and hydraulic valves plumbed between the pivot lateral and goose neck of each drop hose (fig. 1). Sprinkler banks were configured to include six drop hoses (9.1 m width) and controlled by a

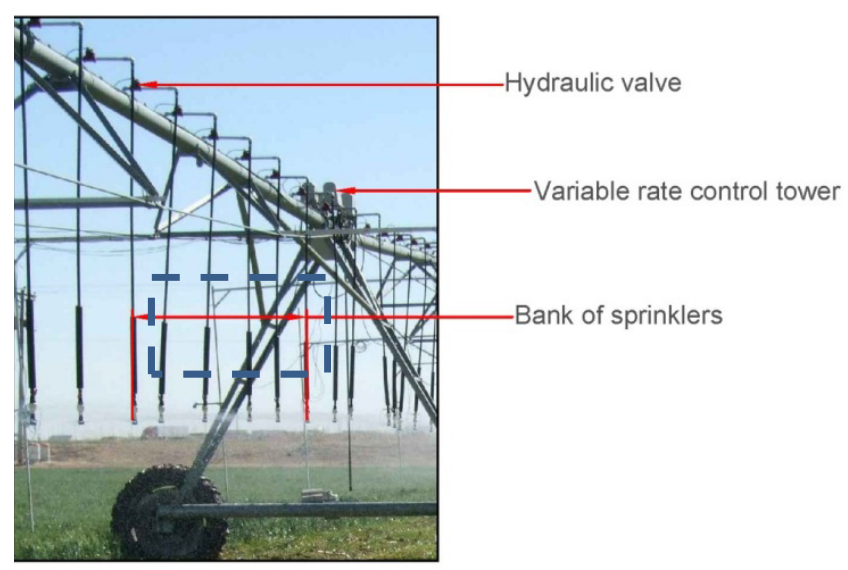

Figure 1. Section of center pivot showing hydraulic valves on each drop hose, variable rate control towers located near the regular tower box, and bank of sprinklers (six drop hoses) which comprise a zone. solenoid valve located at a nearby control tower. The threespan center pivot was configured with 12 banks, and the six-span with 24 banks.

The nozzle sizes were selected to apply water uniformly along the lateral length, irrigation application rates were regulated by "on/off” pulsing of the hydraulic valves. The irrigation rates were prescribed through the VRI software for each catch can trial. The duty cycle (DC) or period of "on" and "off' time for irrigation was established by selecting the cycle time (CT) setting (seconds), irrigation pulsing rate $\left(\mathrm{A}_{\mathrm{r}}\right)(\%)$, and the percent timer setting $\left(T_{\mathrm{s}}\right)(\%)$ (eq. 1). Percent timer is the percentage of time that the end tower moves in $1 \mathrm{~min}$.

$$
\begin{aligned}
D C & =(\text { on })+(\text { off })=\left(\frac{C T}{T_{s}}\right) A_{r} \\
& +\left(\frac{C T}{T_{S}}\right)\left(100-A_{r}\right)
\end{aligned}
$$

The default $C T$ setting of $20 \mathrm{~s}$ was selected for all trials in 2011, and changed to 15 and 10 for some trials in 2012 to evaluate its effect on application uniformity. A $C T=20 \mathrm{~s}$, $T_{\mathrm{s}}=10 \%$, and a pulsing rate of 30 , would produce a $D C=$ $200 \mathrm{~s}$, with the "On" time $=60 \mathrm{~s}$ and the "Off" time $=$ $140 \mathrm{~s}$. Irrigation pulsing rates were in increments of 10 (a function of the VRI software) and ranged from 0 to 100 .

For purposes of the catch can trials, an irrigation management zone was comprised of two banks (total of 12 drop hoses) and both banks were programmed to deliver water at the same rate. Any zones that were not tested had an application of depth of $100 \%$, i.e. they were not pulsed "on or off". The three- and six-span center pivots included 6 and 12 management zones, respectively. Each flexible polyethylene drop hose was $19 \mathrm{~mm}(3 / 4 \mathrm{in}$.) in diameter and equipped with a pressure regulator rated at $41 \mathrm{kPa}(6 \mathrm{psi})$, a fixed plate spray sprinkler with a low drift nozzle (LDN), and a single concave pad (33 grooves) (Senninger Irrigation Inc., Clermont, Fla.). Drop hoses were approximately $1.5 \mathrm{~m}$ above the ground and spaced $1.5 \mathrm{~m}$ apart. Nozzle design flows were between 0.04 and $0.37 \mathrm{~L} \mathrm{~s}^{-1}$ (0.7-5.8 gpm; orifice No. 6-18, sized in $64^{\text {th }}$ of an inch). The center pivot sprinkler operated at an average pressure of $172 \mathrm{kPa}$ (25 psi) at the pivot point. The wetted diameter of the sprinklers ranged between: 6.0 and $7.8 \mathrm{~m}$ on span $1 ; 8.0$ to $8.7 \mathrm{~m}$ on span $2 ; 8.7$ to $9.0 \mathrm{~m}$ on $\operatorname{span} 3 ; 8.9$ to $9.0 \mathrm{~m}$ on span 5; and 9.0 to $9.2 \mathrm{~m}$ on span 6. Arc-wise, the commercial VRI software provided for management zone angular widths ranging from $2^{\circ}$ to $180^{\circ}$.

\section{Catch Can Specifications and Conduct OF MeASUREMENTS}

Catch cans $(152 \mathrm{~mm}$ ht. $\times 154 \mathrm{~mm}$ dia. $)$ were constructed of white rigid polyvinyl chloride (PVC), Schedule-40 (fig. 2). The top portion of each can was beveled to define the catch area precisely. Can height was chosen to help reduce droplet splashout. The cans were placed over mowed wheat, each on a three-legged wire stand. The top of the stand was approximately $70 \mathrm{~mm}$ above the ground and was leveled by adjusting the 


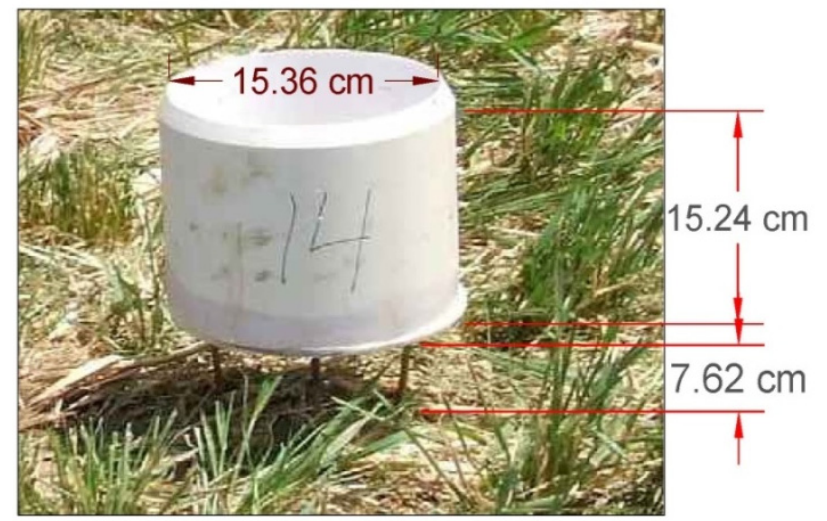

Figure 2. Typical positioning of catch can in the pivot field for uniformity testing.

penetration of the legs into the soil (fig. 2). Prior to each trial, the catch cans were cleaned and vegetable oil was sprayed inside the collector to help subdue evaporative losses. Catch can water volumes were measured using a funnel and a $1 \mathrm{~L}$ graduated cylinder by visual interpretation of the water and oil interface to the nearest $10 \mathrm{~mL}$ $(0.54 \mathrm{~mm})$. The pivot was started approximately $10^{\circ}$ before the approach of the transect line to allow adequate time for the pulsing action of the valves to synchronize. Measurements were made after the pivot moved beyond the target collector(s) and as soon as the spray from the sprinklers was no longer striking the collector(s). The default cycle time (CT) of $20 \mathrm{~s}$ was expected to be the optimal setting for uniformity of application in the outer spans of VRI center pivot system where the travel speed is greater. The CT was varied (to 15 and $10 \mathrm{~s}$ ) when collectors were arranged in an arc-wise pattern in two separate trials in the outer spans of the six-span center pivot to assess its effects on $\mathrm{CU}_{\mathrm{HH}}, \mathrm{DU}_{\mathrm{lq}}$, and accuracy of irrigation depth.

To evaluate application uniformity of the VRI system, the catch cans were arranged into three patterns: (1) transect (line); (2) grid; and (3) arc-wise (fig. 3). The catch cans were placed in the transect pattern to assess uniformity of application within each management zone in the radial direction using different irrigation application rates along the lateral. The transect pattern was also used to determine the amount of overlap at the boundaries of management zones differing in irrigation rate. Grid pattern results were used to assess application uniformity and compare measured irrigation depths to calculated depths in the direction of pivot travel in a manner similar to Chavez et al., 2010. Finally, evaluation of the arc-wise pattern was used to assess uniformity of application and boundary effects in the direction of pivot travel as irrigation rates changed. The transect- and grid-type patterns were combined during the first five trials (2011) and the last four trials (2012) (table 1). Two sets of grids were set up during each transect trial in 2012. Cans were placed in an arc-wise pattern for Trials 7-10 and Trials 11-14. The pivot travel speed was set at $34.5 \mathrm{~m} \mathrm{~h}^{-1}$ at the outer tower for all trials except Trial 5 to obtain a theoretical application depth of $25.4 \mathrm{~mm}$ at $100 \%$ application rate. The travel speed for Trial 5 was reduced to $18.6 \mathrm{~m} \mathrm{~h}^{-1}$ for an expected irrigation
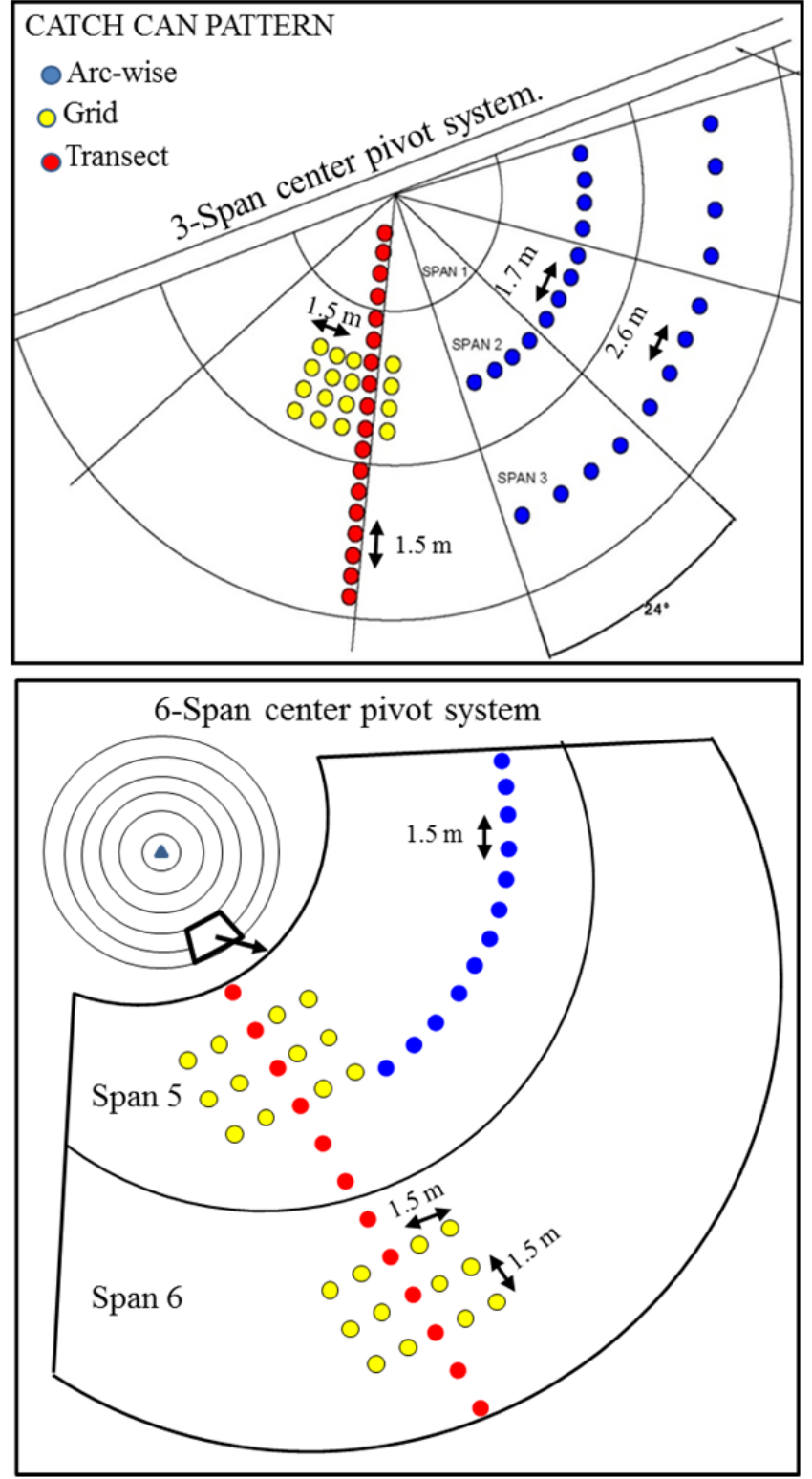

Figure 3. Catch can layout patterns for uniformity testing of variable rate irrigation system over a three- and six-span center pivot systems.

depth of $50 \mathrm{~mm}$ of applied water when the pulsing rate was $100 \%$ (water was always "on").

For the first year of trials (2011), a transect of 70 catch cans was placed radially along spans 1-3 of the three-span pivot lateral (fig. 3). In the following year, a transect of 48 catch cans was placed along spans 5 and 6 of the sixspan center pivot. It was decided that the evaluations on the six-span center pivot be limited to the outer spans since inner spans, i.e. 1-3 were evaluated in 2011 using the threespan pivot. During each trial with a transect pattern, an additional group of 20 catch cans was placed to form a $5 \times$ 5 grid $\left(56.3 \mathrm{~m}^{2}\right)$ within a single irrigation zone to evaluate the application uniformity and accuracy of depth within that irrigation zone. Before each trial, an irrigation prescription map was uploaded to the control panel. The order of the pulsing rates was randomized along the lateral for all transect trials and in the direction of pivot movement (for a set number of degrees) for all arc-wise trials. 
Table 1. Trials, collector patterns, and applied water for uniformity testing of variable rate irrigation center pivot systems.

\begin{tabular}{|c|c|c|c|}
\hline Trial & Transect- Watering Rate & Grid- Watering Rate & Arcwise- Watering Rate \\
\hline \multicolumn{4}{|c|}{2011 Trials: Three-span Center Pivot } \\
\hline 1 & $50,30,50,30,80,100^{[a]}$ & $100($ zone 6, span 3$)$ & - \\
\hline 2 & $30,80,50,100,30,50$ & $50($ zone 6, span 3$)$ & - \\
\hline 3 & $50,100,80,30,50,30$ & 80 (zone 3 , span 2 ) & - \\
\hline 4 & $100,30,50,80,30,50$ & $30($ zone 2, span 1$)$ & - \\
\hline 5 & $100,30,50,80,30,50$ & 30 (zone 2, span 1$)$ & - \\
\hline 6 & $30,50,80$ & -1 & - \\
\hline \multirow[t]{2}{*}{7} & - & & $80,30,100,50,80,100$ \\
\hline & & - & $50,80,100,30,50,100,30$ \\
\hline \multirow[t]{2}{*}{8} & - & & $30,70,100$ \\
\hline & & - & $70,100,30$ \\
\hline \multirow[t]{2}{*}{9} & - & & $70,100,30$ \\
\hline & & - & $30,70,100$ \\
\hline \multirow[t]{2}{*}{10} & - & & $70,30,100$ \\
\hline & & & $100,70,30$ \\
\hline \multicolumn{4}{|c|}{2012 Trials: Six-span Center Pivot } \\
\hline 11 & - & - & $50,80,30$ \\
\hline 12 & - & - & $50,80,30$ \\
\hline 13 & - & - & $80,30,50$ \\
\hline 14 & - & - & $80,30,50$ \\
\hline \multirow[t]{2}{*}{15} & $30,80,50,100$ & $80($ zone 10, span 5$)$ & \\
\hline & & 100 (zone 12, span 6$)$ & - \\
\hline \multirow[t]{2}{*}{16} & $80,30,100,50$ & 80 (zone 9, span 5) & - \\
\hline & & 50 (zone 12, span 6$)$ & \\
\hline \multirow[t]{2}{*}{17} & $100,50,30,80$ & 100 (zone 9, span 5) & - \\
\hline & & 80 (zone 12, span 6$)$ & \\
\hline \multirow[t]{2}{*}{18} & $50,80,70,30$ & 50 (zone 9, span 5) & - \\
\hline & & 30 (zone 12, span 6$)$ & \\
\hline
\end{tabular}

When conducting application uniformity testing using the transect and grid patterns, collectors were spaced $1.5 \mathrm{~m}$ apart and located between drops, such that 12 collectors were located in each irrigation management zone. Trials for the transect pattern were performed in management zones 1-6 (spans 1-3) on the three-span, and zones 9-12 (spans 56) on the six-span center pivot. In the case of the arc-wise patterns, Trials 8-14, the collectors were spaced $1.5 \mathrm{~m}$ apart, and the sector size was $24^{\circ}$. For Trial 6 , collectors were grouped in grids of $3 \times 7,2 \times 14$, and $2 \times 23$ catch cans in spans 1, 2, and 3, respectively. For Trial 7, the prescription map was built using 10 management zones each of $12^{\circ}$ angular width. Ten collectors were spaced 1.3 $\mathrm{m}$ apart in an arc-wise pattern. The range of tested irrigation application depths and pulsing rates were those commonly used in deficit irrigation treatments from prior experiments and allowed assessment of a range of rate changes from low to high irrigation application amounts, as well as the converse.

\section{Calculations}

Application uniformity was evaluated separately for each management zone using the Heermann and Hein (1968) uniformity coefficient $\left(\mathrm{CU}_{\mathrm{HH}}\right)$ :

$$
C U_{H H}=100\left[1-\frac{\sum_{i=1}^{n} S_{i}\left|V_{i}-\overline{V_{p}}\right|}{\sum_{i=1}^{n} V_{i} S_{i}}\right]
$$

where $\mathrm{n}$ is the number of collectors, $i$ is the $i^{\text {th }}$ collector, $V_{i}$ is the volume of water collected in the $i^{\text {th }}$ collector, $S_{\mathrm{i}}$ is the distance of the $i^{\text {th }}$ collector from the pivot point, and $\overline{V_{p}}$ is the weighted average of the volume of collected water in the management zone and calculated as:

$$
\bar{V}_{p}=\frac{\sum_{i=1}^{n} V_{i} S_{i}}{\sum_{i=1}^{n} S_{i}}
$$

In the case of analyzing application uniformity in the direction of pivot travel (catch cans arranged in an arc-wise pattern), $\mathrm{CU}_{\mathrm{HH}}$ reduces to the Christiansen Coefficient (Christiansen, 1942).

The lower quarter distribution uniformity $\left(\mathrm{DU}_{\mathrm{lq}}\right)$ is another measure of spatial uniformity of applied water (Kruse, 1978; Merriam and Keller, 1978). The DU $\mathrm{LU}_{\mathrm{lq}}$ for each management zone was calculated using a modified equation (Dukes and Perry, 2006):

$$
D U_{l q}=100\left(\frac{\sum_{i=1}^{j} S_{i} V_{i} / \sum_{i=1}^{j} S_{i}}{\overline{V_{p}}}\right)
$$

where the numerator is the mean application volume of the lowest one-quarter of collectors $(j)$ in the management zone. The modifications reflect the weighted area represented by each collector.

The mean absolute error (MAE) was calculated to compare how close the measured collector volumes were to the predicted volumes: 


$$
M A E=\frac{1}{n} \sum_{i=1}^{n}\left|\hat{P}_{i}-O_{i}\right|
$$

where $\hat{P}_{i}$ is the predicted volume at position $i$ in the management zone, $O_{i}$ is the corresponding observed value, and $n$ is the number of catch cans used in the zone or sector. The mean bias error (MBE) was calculated to determine the precision of application depth, whereby under-irrigation would be represented by a negative value and overirrigation by a positive value:

$$
M B E=\frac{1}{n} \sum_{i=1}^{n}\left(\hat{P}_{i}-O_{i}\right)
$$

Percent MBE (\%MBE) was based on the measured mean for each management zone, sector, or grid. The root mean square error (RMSE) provided an indication of accuracy between predicted and observed measurements:

$$
R M S E=\sqrt{\frac{\sum_{i=1}^{n}\left(O_{i}-\hat{P}_{i}\right)^{2}}{n}}
$$

The percent RMSE (\%RMSE) was based on the measured mean for each management zone, sector, or grid. Chavez etal. (2010) used the \%MBE and the \%RMSE to characterize the precision and accuracy of the mean collected depth of their linear move VRI system.

The evaporation and drift losses, EDL, were based on the equation of Faci et al. (2001):

$$
E D L=\sum_{i=1}^{n}\left(\frac{V_{c i}-V_{m i}}{V_{c i}}\right) 100
$$

where $V_{c i}(\mathrm{~mm})$ was the calculated (predicted) volume for the $i^{\text {th }}$ collector, and $V_{m i}(\mathrm{~mm})$ was the total measured volume collected at the $i^{\text {th }}$ collector, and $n=$ total number of collectors. The predicted volumes in equations 5-8 were based on methods of Heermann and Hein (1968), where the cumulative depth applied to a single catch can was the summation of water applied from adjacent sprinklers with a wetted radius capable of impacting the $i^{\text {th }}$ collector. Nozzle flows were based on measurements made prior to the start of catch can trials by discharging flow from an individual nozzle system into a $18.75 \mathrm{~L}$ bucket over a known period of time.

\section{QUANTIFICATION OF THE VARIATION IMPOSED WITH THE VARIABLE RATE IRRIGATION (VRI) SYSTEM}

To assess the uniformity of application of the VRI system along the pivot lateral, the mean $\mathrm{CU}_{\mathrm{HH}}$ and mean $\mathrm{DU}_{\mathrm{lq}}$ were calculated for each irrigation zone for collectors established in transect and grid patterns. Because the 25 collectors established in a grid system were well within the boundaries of an irrigation zone, it was assumed that the uniformity of application in this pattern would demonstrate the degree of accuracy of the "on/off" pulsing method of the commercial VRI system.
It was also presumed that there were areas around the borders between adjacent management zones during the transect trials, and around the borders of sectors during the arc-wise trials, which were affected by the different irrigation rates. To determine the radial and arc-wise length for which the application uniformity was affected, the mean $\mathrm{CU}_{\mathrm{HH}}$ and $\mathrm{DU}_{\mathrm{lq}}$ were calculated for the number of collectors (n) placed in the zone (transect trials) or sector (arc-wise trials), and then re-analyzed after excluding two, four, and six collectors from the zone or sector. In the analyses, one, two, or three collectors were excluded from each border of the zone or sector. Mean values of $\mathrm{CU}_{\mathrm{HH}}$ and $\mathrm{DU}_{\mathrm{lq}}$ from each sub-set of collectors were tested for significant differences. A lack of a significant change in the mean value indicated that the operation of the VRI system no longer affected the uniformity of application. The calculated length of 'imposed' variation was the product of the number of collectors excluded and the distance between cans. Ortiz et al. (2010) used similar logic to assure the elimination of border effects imposed by treatment zones on a center pivot configured with zones of different types of sprinkler plates and drop hoses of varying lengths, when assessing the sprinkler's uniformity of application. McCann et al. (1997) increased the size of irrigation cells to reduce border effects from zones of varying irrigation rates. After calculating the uniformity coefficients using different numbers of collectors, each irrigation zone (starting with zone 2) was categorized as a low-to-high $\left(\mathrm{Z}_{\mathrm{L}-\mathrm{H}}\right)$ zone when the subject zone was of a higher irrigation rate than the adjacent zone proximal to the pivot point. Conversely, when the subject zone was of a lower irrigation rate than the adjacent zone proximal to the pivot point, it was classified as a high-to-low $\left(\mathrm{Z}_{\mathrm{H}-\mathrm{L}}\right)$ zone (fig. 4). Using this method, the effects of applying different irrigation rates between neighboring zones could be analyzed.

\section{ChaRaCTERIZATION OF THE EFFECTS OF Wind SPEED AND DIRECTION ON APPLICATION UNIFORMITY}

To assess the effects of wind speed and direction on the application uniformity while operating the VRI system, the

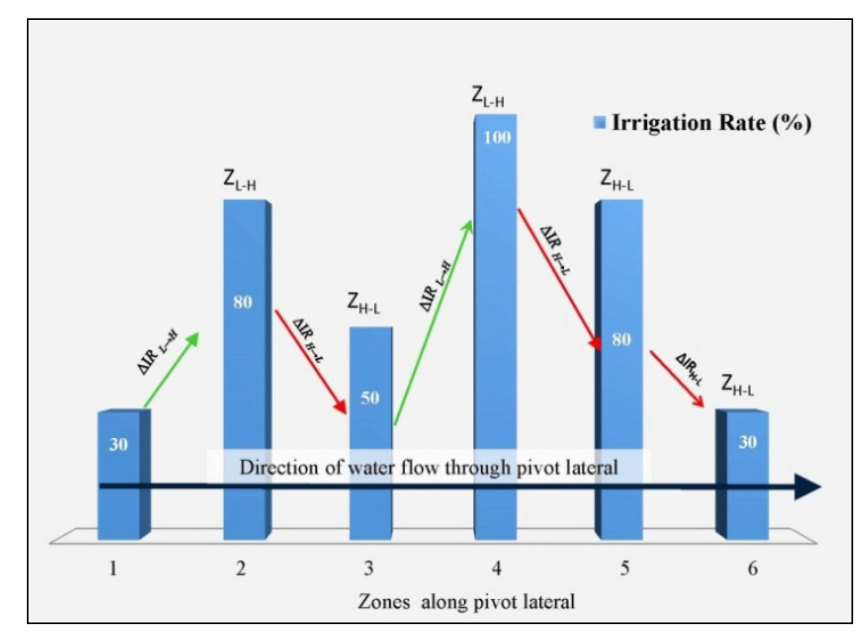

Figure 4. Classification method of irrigation zone along the pivot lateral: (a) low-to-high $\left(\mathrm{Z}_{\mathrm{L}-\mathrm{H}}\right)$; and (b) high-to-low $\left(\mathrm{Z}_{\mathrm{H}-\mathrm{L}}\right)$, with zone 1 located nearest to the pivot point. 
average wind speed $(\mathrm{U})$ was calculated for each catch can trial and grouped into two categories: (1) Low Wind (LW) where $\mathrm{U}<5 \mathrm{~m} \mathrm{~s}^{-1}$; (2) High Wind (HW) where $\mathrm{U} \geq 5 \mathrm{~m} \mathrm{~s}^{-1}$. The prevailing wind direction during each trial was characterized as either: (a) acute or obtuse relative to the transect of catch cans; (b) directed inwards towards the pivot point (ID), or outwards towards the end tower (OD); and (c) in the same (SD) or opposite direction (OD) of pivot movement (fig. 5). The effect of wind speed and direction on application uniformity was then analyzed by reviewing $\mathrm{CU}_{\mathrm{HH}}$ and $\mathrm{DU}_{\mathrm{lq}}$ for each irrigation management zone, and reviewing the changes in $\mathrm{CU}_{\mathrm{HH}}\left(\Delta \mathrm{CU}_{\mathrm{HH}}\right)$ and $\mathrm{DU}_{\mathrm{lq}}\left(\Delta \mathrm{DU} \mathrm{lq}_{\mathrm{lq}}\right)$ between adjacent irrigation zones. Zones were again classified as $\mathrm{Z}_{\mathrm{L}-\mathrm{H}}$ or $\mathrm{Z}_{\mathrm{H}-\mathrm{L}}$.

\section{Statistical Analysis of THE Data}

An analysis of variance (ANOVA) was performed on $\mathrm{CU}_{\mathrm{HH}}$ and $\mathrm{DU}_{\mathrm{LQ}}$ where the spans, watering rate, and catch can patterns were treated as main effects using statistical analysis software Proc Mixed procedure (SAS Institute, Inc., Cary, N.C.). A second ANOVA was used to determine if the means of $\mathrm{CU}_{\mathrm{HH}}$ and $\mathrm{DU}_{\mathrm{lq}}$ between adjacent zones were affected by variable irrigation rates. Means were grouped by $\mathrm{Z}_{\mathrm{L}-\mathrm{H}}$ or $\mathrm{Z}_{\mathrm{H}-\mathrm{L}}$. A separate two-factor ANOVA was made on the means of the $\Delta \mathrm{CU}_{\mathrm{HH}}$ and $\Delta \mathrm{DU}_{\mathrm{lq}}$ calculated between adjacent irrigation zones to evaluate the main effects of wind speed and different irrigation amounts from neighboring zones on application uniformity. Finally, a two-factor ANOVA was performed on the differences between $\mathrm{CU}_{\mathrm{HH}}$ and $\mathrm{DU}_{\mathrm{lq}}$ for adjacent irrigation management zones, to determine if the main effects of wind direction relative to the pivot lateral and the direction of pivot movement grouped by $\mathrm{Z}_{\mathrm{H}-\mathrm{L}}$ and $\mathrm{Z}_{\mathrm{L}-\mathrm{H}}$ significantly influenced application uniformity. Data for Trial 5 was not included in the statistical analysis.

Prior to performing all ANOVA, a normality and equal variance test for $\mathrm{p} \leq 0.05$ was determined with the ShapiroWilk test (Shapiro and Wilk, 1965). For each ANOVA, a multiple comparison of means was accomplished using the Tukey- Kramer test $(p<0.05)$. For all cases where the Shapiro-Wilk test failed, the Kruskal-Wallis one-way ANOVA on ranks was performed (Kruskal and Wallis, 1952). This analysis used a range from $25 \%$ to $75 \%$ of the values in each group, and then, the means were compared using the Student-Newman-Keuls Method (Newman, 1939; Keuls, 1952).

\section{RESUlTS AND DisCUSSION \\ ENVIRONMENTAL CONDITIONS DURING TRIALS}

For the majority of the catch can trials, the average air temperature was relatively cool, ranging from $15^{\circ} \mathrm{C}$ to $26^{\circ} \mathrm{C}$ (Trials 1-6, and 8 in 2011; and Trials 11-14, and 16-17 in 2012), and relative humidity ranged from $13 \%$ to $48 \%$. Air temperature did increase upwards to $28^{\circ} \mathrm{C}-30^{\circ} \mathrm{C}$ later in May for Trials 7, 9-10, 15 and 18 (table 2). The average wind speed was at times greater than recommended by ASAE Standard S436.1 $\left(5 \mathrm{~m} \mathrm{~s}^{-1}\right)$ throughout all the trials; however, we attempted to schedule the catch can trials on days when the wind was not gusting for the short window of time that was available for testing. There was a change in wind direction during almost all the trials; and wind gusts were particularly large during Trials 5,8 , and 10 , and 15 (table 2). High and gusting winds are common at Bushland, Texas, as well as much of the Southern High Plains region.

\section{UNIFORMITY OF APPLICATION \\ Within Irrigation Management Zones}

Typically, the first $20 \%$ of the system length proximal to the pivot point is ignored during uniformity testing since this area represents such a small amount of the total system coverage (Dukes and Perry, 2006). However, since we established research treatment plots in these zones, the assessment of the inner spans were of interest here. An

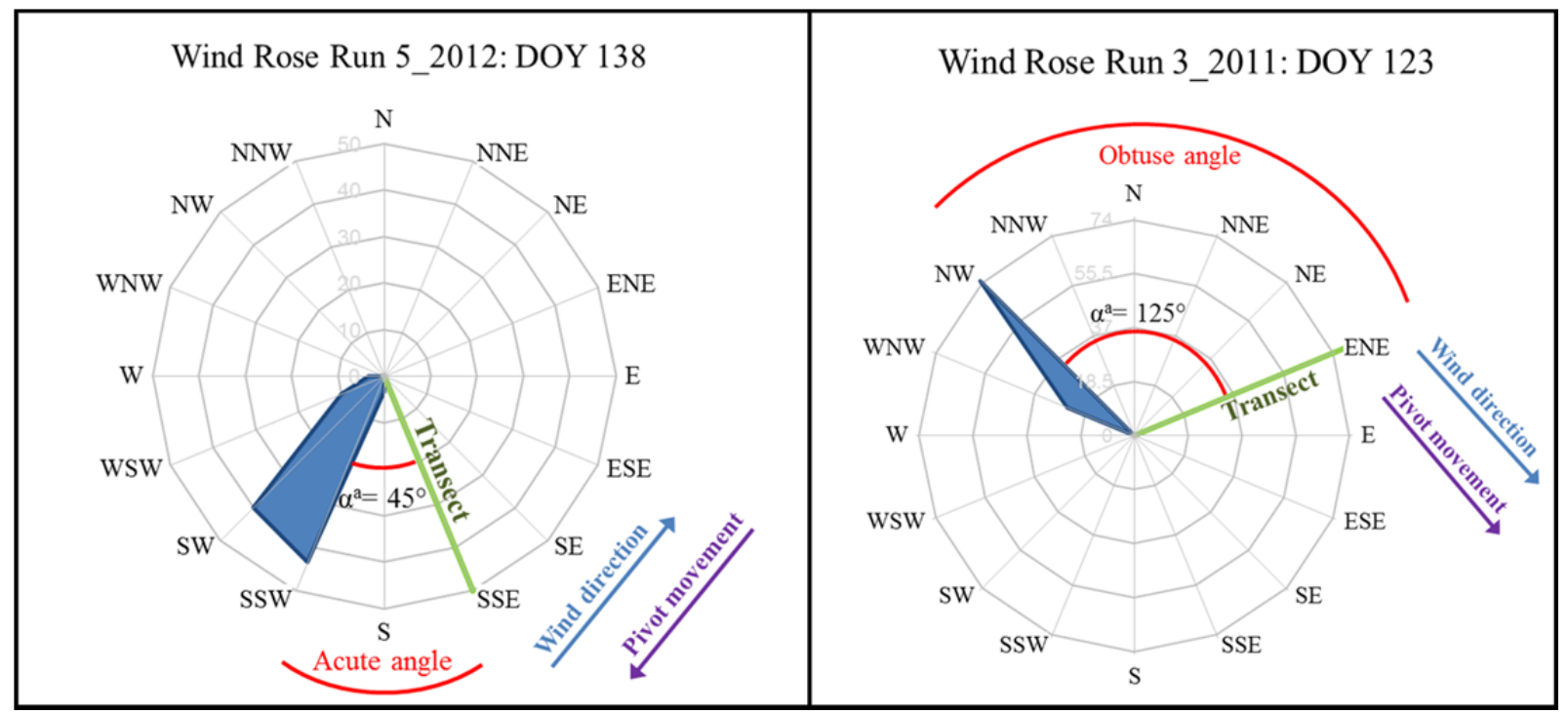

Figure 5. Graph: (left) indicating that the direction of the prevailing wind formed at an acute angle with the transect of collectors and was against the direction of pivot travel (Trial 15, 2012); and (right) demonstrating that the prevailing wind direction was at an obtuse angle relative to the transect of collectors and in the same direction of pivot travel (Trial 3, 2011). 
Table 2. Mean meteorological data during the catch can trials and calculated evaporation and drift loss (EDL).

\begin{tabular}{|c|c|c|c|c|c|c|c|}
\hline DOY & $\begin{array}{c}\text { Trial No. } \\
\text { (Time of day } \\
\text { performed, CST) }\end{array}$ & $\begin{array}{c}\text { Avg. RH } \\
(\%)\end{array}$ & $\begin{array}{c}\text { Avg. } \\
\text { Wind Speed } \\
\left(\mathrm{m} \mathrm{s}^{-1}\right)\end{array}$ & $\begin{array}{c}\text { Wind Gusts } \\
\left(\mathrm{m} \mathrm{s}^{-1}\right)\end{array}$ & $\begin{array}{c}\text { Wind } \\
\text { Direction }\end{array}$ & $\begin{array}{c}\text { Avg. } \\
\text { Air Temp } \\
\left({ }^{\circ} \mathrm{C}\right)\end{array}$ & $\begin{array}{c}\text { EDL } \\
(\%)\end{array}$ \\
\hline 118 & $1:(930-1130)$ & 35 & 5.6 & 6.6 & W,WNW & 16 & 15.4 \\
\hline (28 Apr) & $2:(1330-1500)$ & 17 & 4.4 & 4.9 & W,NW,WSW & 22 & 16.2 \\
\hline 123 & $3:(1000-1100)$ & 27 & 5.7 & 6.9 & $\mathrm{~N}, \mathrm{NW}$ & 15 & 1.5 \\
\hline (3 May) & $4:(1400-1530)$ & 13 & 5.5 & 5.9 & NNW & 21 & 1.0 \\
\hline $\begin{array}{c}126 \\
\text { (6 May) }\end{array}$ & $5:(930-1100)$ & 18 & 9.5 & 11.9 & SSE, S & 26 & 19.0 \\
\hline $\begin{array}{c}132 \\
\text { (12 May) }\end{array}$ & $6:(1300-1500)$ & 29 & 4.1 & 4.9 & $\mathrm{~S}$ & 20 & $\mathrm{NC}^{[\mathrm{a}]}$ \\
\hline $\begin{array}{c}143 \\
\text { (23 May) }\end{array}$ & $7:(830-1840)$ & 13 & 4.3 & 6.5 & WNW, N, ENE & 30 & $\mathrm{NC}$ \\
\hline $\begin{array}{c}146 \\
\text { (26 May) }\end{array}$ & $8:(830-1500)$ & 32 & 5.0 & 10.3 & NE,E,S,SE & 23 & $\mathrm{NC}$ \\
\hline $\begin{array}{c}147 \\
\text { (27 May) }\end{array}$ & $9:(830-1500)$ & 19 & 5.0 & 7.9 & NW,NE & 28 & $\mathrm{NC}$ \\
\hline $\begin{array}{c}152 \\
\text { (1 June) }\end{array}$ & $10:(830-1500)$ & 42 & 8.2 & 12.2 & $\mathrm{~S}, \mathrm{SE}$ & 30 & $\mathrm{NC}$ \\
\hline $\begin{array}{c}89 \\
(29 \text { Mar) }\end{array}$ & 11: (930-1330) & 15 & 2 & 5.2 & W,WNW,NNW,N & 25 & $\mathrm{NC}$ \\
\hline $\begin{array}{c}90 \\
\text { (30 Mar) }\end{array}$ & 12: (1000-1400) & 54 & 4 & 5.4 & N,NNE,NE & 21 & $\mathrm{NC}$ \\
\hline $\begin{array}{c}130 \\
\text { (9 May) }\end{array}$ & 13: (930-1330) & 28 & 1.4 & - & SSE,S,SSW,SW & 21 & $\mathrm{NC}$ \\
\hline $\begin{array}{c}131 \\
\text { (10 May) }\end{array}$ & 14: (930-1330) & 43 & 4.1 & 5.2 & SSE,S,SSW & 20 & $\mathrm{NC}$ \\
\hline $\begin{array}{c}138 \\
\text { (17 May) }\end{array}$ & 15: (1230-1300) & 18 & 7.9 & 8.3 & SSW,SW & 28 & 13.8 \\
\hline $\begin{array}{c}139 \\
\text { (18 May) }\end{array}$ & $16:(9: 30-10: 00)$ & 30 & 4.8 & 5.3 & SW,WSW,W & 25 & 1.8 \\
\hline $\begin{array}{c}142 \\
\text { (21 May) }\end{array}$ & 17: (1300-1330) & 48 & 4.4 & 5.3 & S,SSW,SW & 25 & 8.3 \\
\hline $\begin{array}{c}145 \\
\text { (24 May) }\end{array}$ & 18: (1400-14:30) & 18 & 3.4 & 5.4 & SW,SSW & 30 & 6.7 \\
\hline
\end{tabular}

ANOVA indicated that the $\mathrm{CU}_{\mathrm{HH}}$ and $\mathrm{DU}_{\mathrm{lq}}$ were not significantly influenced by span location. Mean $\mathrm{CU}_{\mathrm{HH}}$ and $\mathrm{DU}_{\mathrm{lq}}$ ranged from $86.3 \%$ to $89.5 \%$, and $76.3 \%$ to $82.9 \%$, respectively (table 3, Columns I and II). These mean values compared well to uniformity of application outcomes $\left(\mathrm{CU}_{\mathrm{HH}}=90 \%\right)$ obtained by Clark et al. (2003), using a conventional center pivot system outfitted with fixed-plate low drift nozzle sprinklers spaced at $1.5 \mathrm{~m}$ and operated at $41 \mathrm{kPa}$. Yet, our values were higher than values reported by Dukes and Perry (2006), where the $\mathrm{CU}_{\mathrm{HH}}$ and $\mathrm{DU}_{\mathrm{lq}}$ ranged from $73 \%$ to $82 \%$ and $64 \%$ to $74 \%$, respectively, for a linear move VRI system outfitted with fixed spray plate LDN. The higher uniformity achieved in our study may be attributed to narrower sprinkler spacing (1.5 vs. $2.3 \mathrm{~m})$. On the other hand, our results were within the lower range of those reported by Han et al. (2009) (79.5\%, 91.7\%, 94.0\%, and $94.8 \%$ ) for a linear move VRI system with rotator nozzles spaced $3.0 \mathrm{~m}$ apart and drop hoses raised $2.0 \mathrm{~m}$ above the ground. Reasons for this difference may include different sprinkler packages (fixed- vs. moving-spray plates) and the lower operating pressure (41 vs. $140 \mathrm{kPa}$ ) of the center pivot in this study versus the linear move VRI systems in the published studies. According to Clark et al. (2003) operating sprinklers with LDN at lower pressures (41 and $69 \mathrm{kPa}$ ) resulted in more varied $\mathrm{CU}_{\mathrm{HH}}$ values than their operation at higher pressures $(104$ and $138 \mathrm{kPa})$.

In our studies, the mean $\mathrm{CU}_{\mathrm{HH}}$ was significantly reduced in management zones applying $7.6 \mathrm{~mm}$ (pulsing rate $=30 \%$ rate) as compared with the mean $\mathrm{CU}_{\mathrm{HH}}$ in irrigation management zones pulsing at rates $>50 \%$. Although not significantly different, the $\mathrm{DU}_{\mathrm{lq}}$ also decreased as irrigation application rates decreased. Dukes and Perry (2006) and Han et al. (2009) reported lower $\mathrm{CU}_{\mathrm{HH}}$ and $\mathrm{DU}_{\mathrm{lq}}$ results at application rates of $25 \%$ of $25 \mathrm{~mm}$ for a VRI center pivot, and a VRI linear move system, both outfitted with moving spray plate sprinklers. These results are not surprising since nozzles with smaller diameters produce smaller drops (Solomon et al., 1985), which are more prone to evaporative losses (Frost and Schwalen, 1955) and drift due to less mass.

\section{Direction of Sprinkler Travel}

Application uniformity results from collectors in the grid pattern produced significantly greater $\mathrm{CU}_{\mathrm{HH}}(92.5 \%)$ and $\mathrm{DU}_{\mathrm{lq}}(90.5 \%)$ values than those from transect and arcwise patterns (table 3, column 2). This was expected because collectors were located at least $3.8 \mathrm{~m}$ away from adjacent management zones, buffering spray drifting from a management zone of a different irrigation application rate. The $\mathrm{CU}_{\mathrm{HH}}$ was largest $(95.0 \%$ to $96.8 \%)$ during Trials 3 and 16 in which the collectors were in a grid pattern in the last zones of the three- and six-span center pivot systems, respectively. Application depths for these zones ranged from 20 to $25 \mathrm{~mm}$ (pulsing rates of $80 \%$ and $100 \%$, respectively). These mean values of $\mathrm{CU}_{\mathrm{HH}}$ were similar to results reported by Chavez et al. (2010) $\left(\mathrm{CU}_{\mathrm{HH}}=96.5 \%\right)$ for a linear move VRI system having rotator spray plate sprinklers spaced $3 \mathrm{~m}$ apart, and nozzles $1.2 \mathrm{~m}$ above the 
Table 3. Combined results for uniformity of application ( $\bar{C}_{H H}$ and $\overline{D U}_{l q}$ ), error analysis (MAE, MBE, and RMSE), and mean evaporation and drift losses $(\overline{E D L})$ from catch-can trials on the three- and six-span center pivot systems. ${ }^{\text {a] }}$

\begin{tabular}{|c|c|c|c|c|c|c|c|c|c|c|}
\hline & $\begin{array}{c}\overline{C U}_{H H} \\
(\%)^{[\mathrm{b}]}\end{array}$ & $\begin{array}{c}\overline{D U}_{l q} \\
(\%)\end{array}$ & $\begin{array}{l}\overline{M A E} \\
(\mathrm{~mm})\end{array}$ & $\begin{array}{l}\overline{M B E} \\
(\mathrm{~mm})\end{array}$ & $\begin{array}{c}\mathrm{MBE} \\
(\%)\end{array}$ & $\begin{array}{c}\overline{R M S E} \\
(\mathrm{~mm})\end{array}$ & $\begin{array}{c}\text { RMSE } \\
(\%)\end{array}$ & $\mathrm{N}^{[\mathrm{c}]}$ & $\begin{array}{l}\overline{E D L} \\
(\%)\end{array}$ & $\mathrm{n}_{(\mathrm{EDL})}$ \\
\hline \multicolumn{11}{|c|}{ Catch-can location } \\
\hline Span 1 & $88.0 \mathrm{a}$ & $80.1 \mathrm{a}$ & $1.9 \mathrm{a}$ & $1.1 \mathrm{a}$ & $8 a$ & $1.8 \mathrm{a}$ & $10 \mathrm{a}$ & 11 & $10.4 \mathrm{a}$ & 7 \\
\hline Span 2 & $87.7 \mathrm{a}$ & $82.4 \mathrm{a}$ & $2.6 \mathrm{a}$ & $1.1 \mathrm{a}$ & $9 \mathrm{a}$ & $2.4 \mathrm{a}$ & $15 \mathrm{a}$ & 30 & $2.8 \mathrm{a}$ & 7 \\
\hline Span 3 & $89.5 \mathrm{a}$ & $82.9 \mathrm{a}$ & $2.0 \mathrm{a}$ & $0.2 \mathrm{a}$ & $4 a$ & $2.1 \mathrm{a}$ & $12 \mathrm{a}$ & 19 & $5.5 \mathrm{a}$ & 8 \\
\hline Span 5 & $87.9 \mathrm{a}$ & $82.8 \mathrm{a}$ & $2.2 \mathrm{a}$ & $-0.2 \mathrm{a}$ & $-1 \mathrm{a}$ & $2.1 \mathrm{a}$ & $17 \mathrm{a}$ & 24 & $9.4 \mathrm{a}$ & 14 \\
\hline Span 6 & $86.3 \mathrm{a}$ & $76.3 \mathrm{a}$ & $2.1 \mathrm{a}$ & $-0.6 \mathrm{a}$ & $-1 \mathrm{a}$ & $2.3 \mathrm{a}$ & $17 \mathrm{a}$ & 12 & $-1.6 \mathrm{a}^{[\mathrm{d}]}$ & 14 \\
\hline \multicolumn{11}{|c|}{ Application rates (\%) } \\
\hline 30 & $84.4 b$ & $77.8 \mathrm{a}$ & $1.6 \mathrm{~b}$ & $1.3 \mathrm{a}$ & $14 \mathrm{a}$ & $1.8 \mathrm{~b}$ & $21 a$ & 29 & $-2.4 b$ & 6 \\
\hline 50 & $88.2 \mathrm{a}$ & $81.3 \mathrm{a}$ & $2.4 \mathrm{ab}$ & $1.2 \mathrm{a}$ & $9 \mathrm{ab}$ & $2.1 \mathrm{ab}$ & $14 b$ & 22 & $3.3 \mathrm{ab}$ & 6 \\
\hline 70 & $90.5 \mathrm{a}$ & $82.9 \mathrm{a}$ & $2.0 \mathrm{ab}$ & $-0.2 \mathrm{ab}$ & $-3 b c$ & $2.0 \mathrm{ab}$ & $12 \mathrm{ab}$ & 7 & $9.0 \mathrm{ab}$ & 1 \\
\hline 80 & $90.8 \mathrm{a}$ & $84.2 \mathrm{a}$ & $2.6 a b$ & $-0.1 \mathrm{ab}$ & $-1 b c$ & $2.5 \mathrm{ab}$ & $11 b$ & 18 & $8.1 \mathrm{ab}$ & 6 \\
\hline 100 & $90.0 \mathrm{a}$ & $82.9 \mathrm{a}$ & $3.4 \mathrm{a}$ & $-1.3 b$ & $-6 c$ & $2.9 \mathrm{a}$ & $11 b$ & 19 & $18.3 \mathrm{a}$ & 5 \\
\hline \multicolumn{11}{|c|}{ Catch-can pattern } \\
\hline Transect & $87.6 \mathrm{~b}$ & $80.0 \mathrm{~b}$ & $2.4 \mathrm{a}$ & $-0.5 a$ & $-1 b$ & $2.1 \mathrm{ab}$ & $15 \mathrm{a}$ & 45 & $0.7 \mathrm{a}$ & 40 \\
\hline Grid & $92.5 \mathrm{a}$ & $90.5 \mathrm{a}$ & $2.0 \mathrm{a}$ & $0.6 \mathrm{a}$ & $3 a b$ & $1.5 \mathrm{~b}$ & $10 \mathrm{a}$ & 15 & $5.9 \mathrm{a}$ & 12 \\
\hline Arc-wise & $87.6 \mathrm{~b}$ & $81.8 b$ & $2.2 \mathrm{a}$ & $1.4 \mathrm{a}$ & $9 a$ & $2.6 \mathrm{a}$ & $16 \mathrm{a}$ & 40 & $\mathrm{NC}^{[\mathrm{e}]}$ & - \\
\hline \multicolumn{11}{|l|}{ Cycle time (s) } \\
\hline 10 & $84.5 \mathrm{a}$ & $78.9 \mathrm{a}$ & $2.0 \mathrm{a}$ & $1.1 \mathrm{a}$ & $11 \mathrm{a}$ & $1.7 \mathrm{a}$ & $15 \mathrm{a}$ & 3 & $\mathrm{NC}$ & - \\
\hline 15 & $87.2 \mathrm{a}$ & $81.5 \mathrm{a}$ & $1.9 \mathrm{a}$ & $1.9 \mathrm{a}$ & $17 \mathrm{a}$ & $2.8 \mathrm{a}$ & $21 \mathrm{a}$ & 3 & $\mathrm{NC}$ & - \\
\hline 20 & $88.4 \mathrm{a}$ & $82.5 \mathrm{a}$ & $2.3 \mathrm{a}$ & $-0.7 \mathrm{a}$ & $-2 \mathrm{a}$ & $2.2 \mathrm{a}$ & $17 \mathrm{a}$ & 6 & $\mathrm{NC}$ & - \\
\hline
\end{tabular}

[a] Data from Trial 5 (2011) is not included in this analysis.

[b] Letters of the same value in each column indicate no significant difference.

[c] $\mathrm{N}$ is the number of samples in each category.

[d] Negative values indicate a gain in collected depth.

[e] NC-not calculated.

ground moving over a $8 \times 20$ grid of catch cans arranged $1.5 \mathrm{~m}$ apart.

Reviewing uniformity of application in the direction of pivot travel with catch cans arranged in an arc-wise pattern, the mean $\mathrm{CU}_{\mathrm{HH}}$ and $\mathrm{DU}_{\mathrm{lq}}$ were $87.6 \%$ and $81.8 \%$, respectively (table 3 , column 1 , section 3 ). The smallest $\mathrm{CU}_{\mathrm{HH}}(70 \%)$ was during arc-wise Trials 7 and 10 in zone 2 of span 1 when the application depth $=7.6 \mathrm{~mm}(30 \%$ pulsing rate). This reduction in $\mathrm{CU}_{\mathrm{HH}}$ may have been due to the changes in wind direction during the course of the trials (table 2) and to evaporation and drift losses for reasons discussed earlier. The application uniformity was highest $(95 \%)$ in Trial 10 for a pulsing rate of $100 \%$ under average wind speeds of $8.0 \mathrm{~m} \mathrm{~s}^{-1}$. Cycle times varied from the default of $20 \mathrm{~s}$ during arc-wise pattern trials 12 and 14 . No appreciable differences were observed between the values of $\mathrm{CU}_{\mathrm{HH}}$ and $\mathrm{DU}_{\mathrm{lq}}$ obtained from cycle times of 10,15 , and $20 \mathrm{~s}$. However, application uniformity tended to increase as the cycle time increased.

\section{Accuracy of Measured Depth}

Error analysis for the three- and six-span center pivot systems indicated that the MAE, MBE, and RMSE ranged from 1.9 to $2.6 \mathrm{~mm},-0.6$ to $1.1 \mathrm{~mm}$, and 1.8 to $2.4 \mathrm{~mm}$, among spans (table 3 ). On average, sprinklers in spans 1 and 2 over irrigated by approximately $9 \%$, while those in spans 5 and 6 under irrigated by approximately $2 \%$. The $\% \mathrm{MBE}$ and \%RMSE for collectors in irrigation zones with pulsing rates from $30 \%$ to $100 \%$, ranged from $-6 \%$ to $14 \%$, and from $11 \%$ to $21 \%$, respectively. In their linear move VRI study, Chavez et al. (2010) reported that \%MBE and $\%$ RMSE for measured catch can depths for target percent application rates between $20 \%$ and $100 \%$ ranged between $0.6 \%$ to $-11.8 \%$ and $3.0 \%$ to $8.9 \%$, respectively, when the linear move was traveling uphill. When traveling downhill the $\% \mathrm{MBE}$ and $\% \mathrm{RMSE}$ were $-8.3 \%$ to $18.9 \%$ and $3.5 \%$ to $11.7 \%$, respectively. When their control system was transferred to a linear move in North Dakota, the \%MBE and \%RMSE were $-8.8 \pm 8.1 \%$ and $-0.14 \% \pm 6.7 \%$, respectively. While \%MBE for the center pivot VRI systems in this study were similar to those reported by Chavez et al. (2010), the \%RMSE were greater. These larger errors were from collectors located in irrigation zones pulsing at a rate of $30 \%$ and were likely caused by high wind conditions. King et al. (2005) recorded catch values under low wind conditions that were within $5 \%$ of the target application depth over a $36 \%$ to $100 \%$ range in application rate using prototype variable sprinklers made with a retractable pin. The design of the pin-retractable VRI system and the low wind speeds may have contributed to these lower percent errors in prescribed depth applied.

The MAE and RMSE for the $100 \%, 80 \%, 50 \%$, and $30 \%$ irrigation application rates (of $25.4 \mathrm{~mm}$ ) were 1.6 , 2.4, 2.0, 2.6, and $3.9 \mathrm{~mm}$ and 2.1, 1.4, 1.4, and $1.2 \mathrm{~mm}$ for collectors arranged in a grid pattern. When testing a VRI center pivot system, McCann et al. (1997) observed commensurate average deviations in measured depth for collectors in a grid pattern and located in the center of established irrigation zones were $2.9,1.8$, and $1.1 \mathrm{~mm}$ for irrigation application rates of $100 \%, 75 \%$, and $50 \%$ of 25.4 $\mathrm{mm}$. The RMSE values for irrigation depths collected in the direction of pivot travel when cans were arranged in an arcwise pattern were $3.2,2.9,2.1,2.8$, and $2.0 \mathrm{~mm}$ for the irrigation application rates of $100 \%, 80 \%, 70 \%, 50 \%$, and $30 \%$, respectively (data not shown in table 3 ). The RMSE for the measured application depths that were pulsed were less, although not significantly different, from irrigations at $100 \%$ when water flow was not regulated by pulsing. 
The MAE and RMSE for the cycle times of 10, 15, and $20 \mathrm{~s}$ were $2.0,1.9$, and $2.3 \mathrm{~mm}$, and $1.7,2.8$, and $2.2 \mathrm{~mm}$, respectively (table 3 ). The errors were similar among the different cycle times. All other studies reported for VRI systems use a duty cycle of $60 \mathrm{~s}$, which would equate to a $6 \mathrm{~s}$ cycle time for our center pivot machines. We were not able to program a cycle time at this lower rate during our catch can trials due to limitations in the VRI software at the time of the trials. However, now that it is possible to input cycle times manually for each management zone, investigating the impact of lower cycle times in different spans on the subject VRI systems may be an area of future investigation.

\section{Variation between Irrigation Zones}

The significant reduction of $\mathrm{CU}_{\mathrm{HH}}$ and $\mathrm{DU}_{\mathrm{lq}}$ for collectors in transect patterns as compared to the grid pattern (table 3) demonstrated that the borders between irrigation zones and sectors were affected by operation of the VRI system, i.e. irrigating adjacent zones at different rates. Some variability was expected because of sprinkler overlap due to the diameter of throw from sprinklers near the borders of each zone. As suggested by Omary et al. (1997) use of half-circle nozzles at the ends of irrigation management zone may improve overall uniformity. The radial length that was affected (between management zones) was approximately $3 \mathrm{~m}$ for the three-span pivot and between 6 and $9 \mathrm{~m}$ for the six-span center pivot system, during variable rates of irrigation application (table 4). The length of variability was within the range of the wetted radius for the size of nozzles that were used on the threespan center pivot. However, the measured variability along the length of the six-span center pivot was greater than could be explained by the wetted radius of these nozzles and may be due to the wind speed and direction.
Other studies that report on the width or use of the borders for variable rate irrigation assessment are limited. McCann et al. (1997) reported that after making irrigation plots larger (from 81.2 to $331.2 \mathrm{~m}^{2}$ ) and maintaining the location of the grid pattern of catch cans within the center of the plot, the average deviation of measured depths were reduced to one-third of $2.9,1.8$, and $1.1 \mathrm{~mm}$ for adjacent irrigation zones of $100 \%, 75 \%$, and $50 \%$. Their strategy effectively increased the boundary between sprinklers irrigating at different application depths. Ortiz et al. (2010) implemented a $10 \mathrm{~m}$ border between adjacent irrigation zones of differing application rates and performed application uniformity testing over collectors arranged in two transects using a conventional center pivot system. Their results for $\mathrm{CU}_{\mathrm{HH}}$ ranged between $73.8 \%$ and $81.0 \%$ when using fixed spray plates with sprinklers at 2.5 and $1.0 \mathrm{~m}$ above the ground with the $10 \mathrm{~m}$ borders on either side of the transect of cans. Our results for $\mathrm{CU}_{\mathrm{HH}}$ and $\mathrm{DU}_{\mathrm{lq}}$ were much greater even when collectors bordering each irrigation management zone were included in the analysis. Under-sized catch cans may have contributed to low values for Oritz et al. (2010).

Variation imposed by the VRI system in the direction of pivot travel was characterized by assessing the changes in mean $\mathrm{CU}_{\mathrm{HH}}$ and $\mathrm{DU}_{\mathrm{lq}}$ from catch cans arranged in an arcwise pattern. Mean $\mathrm{CU}_{\mathrm{HH}}$ and $\mathrm{DU}_{\mathrm{lq}}$ values for the threeand six-span center pivot systems in this pattern were $89.0 \%$ and $84.0 \%$, and $86.0 \%$ and $79.5 \%$, respectively (table 4). The mean coefficient and distribution of uniformity did not change significantly when re-calculated after excluding catch cans (1 to 3 ) from each bordering edge of the sector of either a $12^{\circ}$ or $24^{\circ}$ angular width. These results indicate that the VRI system imposes minimal variation in the direction of pivot travel when the prescribed irrigation depth is changed.

Table 4. Mean coefficient of uniformity (..) and mean distribution uniformity ( $\left.\overline{D U}_{l q}\right)$ grouped by collector pattern and changes in application depth between adjacent zones or sectors for both the three- and six-span center pivot systems for 2011 and 2012.

\begin{tabular}{|c|c|c|c|c|c|c|c|c|}
\hline \multirow[b]{3}{*}{ Pattern } & \multirow[b]{3}{*}{$\begin{array}{l}\text { Center } \\
\text { Pivot } \\
\text { System }\end{array}$} & \multirow[b]{3}{*}{$\begin{array}{c}\text { Affected } \\
\text { Length }(\mathrm{m}) / \\
\text { Collectors }^{[\mathrm{b}]}\end{array}$} & \multicolumn{6}{|c|}{ Application Uniformity $^{[a]}$} \\
\hline & & & \multicolumn{3}{|c|}{$\mathrm{Z}_{\mathrm{L}-\mathrm{H}}$} & \multicolumn{3}{|c|}{$\mathrm{Z}_{\mathrm{H}-\mathrm{L}}$} \\
\hline & & & $\mathrm{N}^{[\mathrm{c}]}$ & $\begin{array}{c}\overline{C U}_{H H} \\
(\%)^{[\mathrm{d}]}\end{array}$ & $\begin{array}{c}\overline{D U}_{l q} \\
(\%)\end{array}$ & $\mathrm{N}$ & $\begin{array}{c}\overline{C U}_{H H} \\
(\%)\end{array}$ & $\begin{array}{c}\overline{D U}_{l q} \\
(\%)\end{array}$ \\
\hline \multirow{8}{*}{ Transect } & \multirow{4}{*}{ 3-span } & $0 / 12$ & & $89.8 \mathrm{~b}$ & $83.3 \mathrm{~b}$ & \multirow{4}{*}{5} & $89.4 \mathrm{~b}$ & $84.1 \mathrm{~b}$ \\
\hline & & $3 / 10$ & 5 & $93.5 \mathrm{a}$ & $90.5 b$ & & $92.8 \mathrm{ab}$ & $90.2 \mathrm{ab}$ \\
\hline & & $6 / 8$ & $J$ & $95.2 \mathrm{a}$ & $92.6 \mathrm{ab}$ & & $94.3 \mathrm{a}$ & $90.0 \mathrm{ab}$ \\
\hline & & $9 / 6$ & & $95.3 \mathrm{a}$ & $94.0 \mathrm{a}$ & & $94.5 \mathrm{a}$ & $92.0 \mathrm{a}$ \\
\hline & \multirow{4}{*}{ 6-span } & $0 / 12$ & & $84.6 \mathrm{c}$ & $81.5 b$ & \multirow{4}{*}{6} & $86.6 \mathrm{c}$ & $79.2 \mathrm{c}$ \\
\hline & & $3 / 10$ & 4 & $87.0 \mathrm{bc}$ & $84.4 \mathrm{~b}$ & & $89.4 b c$ & $85.6 \mathrm{~b}$ \\
\hline & & $6 / 8$ & 4 & $90.0 \mathrm{~b}$ & $87.0 \mathrm{~b}$ & & 91.9ab & $88.0 \mathrm{ab}$ \\
\hline & & $9 / 6$ & & $93.2 \mathrm{a}$ & $92.0 \mathrm{a}$ & & $93.2 \mathrm{a}$ & $91.8 \mathrm{a}$ \\
\hline \multirow{8}{*}{ Arc-Wise } & \multirow{4}{*}{ 3-span } & $0 / 12$ & \multirow{4}{*}{14} & $89.0 \mathrm{a}$ & $84.0 \mathrm{a}$ & \multirow{4}{*}{9} & $86.0 \mathrm{a}$ & $81.0 \mathrm{a}$ \\
\hline & & $4 / 10$ & & $89.5 \mathrm{a}$ & $85.0 \mathrm{a}$ & & $87.5 \mathrm{a}$ & $84.0 \mathrm{a}$ \\
\hline & & $7 / 8$ & & $89.0 \mathrm{a}$ & $86.5 \mathrm{a}$ & & $89.4 \mathrm{a}$ & $87.0 \mathrm{a}$ \\
\hline & & $11 / 6$ & & $91.5 \mathrm{a}$ & $87.0 \mathrm{a}$ & & $91.2 \mathrm{a}$ & $89.0 \mathrm{a}$ \\
\hline & \multirow{4}{*}{ 6-span } & $0 / 12$ & 4 & $86.0 \mathrm{a}$ & $79.5 \mathrm{a}$ & 4 & $88.5 \mathrm{a}$ & $81.7 \mathrm{a}$ \\
\hline & & $4 / 10$ & & $86.5 \mathrm{a}$ & $81.5 \mathrm{a}$ & & $90.0 \mathrm{a}$ & $83.5 \mathrm{a}$ \\
\hline & & $7 / 8$ & & $86.5 \mathrm{a}$ & $81.5 \mathrm{a}$ & & $90.0 \mathrm{a}$ & $83.7 \mathrm{a}$ \\
\hline & & $11 / 6$ & & $87.5 \mathrm{a}$ & $82.5 \mathrm{a}$ & & $90.5 \mathrm{a}$ & $85.2 \mathrm{a}$ \\
\hline \multirow{2}{*}{\multicolumn{3}{|c|}{$\begin{array}{l}Z_{\mathrm{L}-\mathrm{H}} \text { represents a transition from a zone of a le } \\
\text { lesser irrigation amount. } \\
\text { Number of collectors used to calculate } \overline{C U}_{H H} \\
\mathrm{~N} \text { is the number of samples in each category. }\end{array}$}} & & & & & $\mathrm{Z}_{\mathrm{H}-\mathrm{L}}, \mathrm{a}$ & a great \\
\hline & & & & & & & & \\
\hline
\end{tabular}




\section{EFFECTS OF WIND SPEED AND WIND DIRECTION ON APPLICATION UNIFORMITY AND EDL}

Using wind speed as a main effect in the ANOVA, it was shown that wind improved the $\mathrm{CU}_{\mathrm{HH}}$ and $\mathrm{DU}_{\mathrm{lq}}$ in an irrigation zone adjacent but distal to an irrigation zone of a lower application rate $\left(\mathrm{Z}_{\mathrm{L}-\mathrm{H}}\right)$. For trials conducted under higher wind conditions (HW), $\mathrm{U} \geq 5 \mathrm{~m} \mathrm{~s}^{-1}$, the mean $\Delta \mathrm{CU}_{\mathrm{HH}}(8.0 \%)$ and the mean $\Delta \mathrm{DU}_{\mathrm{lq}}(4.5 \%)$ were greater, but not significantly different than changes under low wind (LW) conditions where mean $\Delta \mathrm{CU}_{\mathrm{HH}}=4.2 \%$ and mean $\Delta \mathrm{DU}_{\mathrm{lq}}=2.0 \%(\mathrm{p} \leq 0.05)$ (table 5$)$. However, wind reduced the uniformity of application in the case of a lower irrigation zone adjacent but distal to an irrigation zone of a greater application rate $\left(\mathrm{Z}_{\mathrm{H}-\mathrm{L}}\right)$ (table 5). Similarly, Hanson and Orloff (1996) observed improvement in $\mathrm{CU}_{\mathrm{HH}}$ under windy conditions of 2.2 to $4.5 \mathrm{~m} \mathrm{~s}^{-1}$ using fixed plate spray nozzles (3.0 m apart) on conventional center pivot systems, as did Dukes (2006) using a linear move with LDN sprinklers $(2.3 \mathrm{~m}$ apart), system pressure $<97 \mathrm{kPa}$, and wind speeds of 5.0 to $6.6 \mathrm{~m} \mathrm{~s}^{-1}$. Hills and Barragan (1998) reported that wind speeds up to $6.2 \mathrm{~m} \mathrm{~s}^{-1}$ had little effect on application uniformity for a conventional moving lateral with fixed-spray plates $(2 \mathrm{~m}$ apart). Under field and laboratory studies, Clark et al. (2003) observed lower uniformity of application for lower operating pressure systems and wider sprinkler spacing when testing LDN sprinklers. Higher wind speeds and reduced sprinkler spacing $(1.5 \mathrm{~m})$ on our two center pivot systems likely influenced favorable $\mathrm{CU}_{\mathrm{HH}}$ values in our studies.

Wind direction appreciably influenced evaporation and drift losses. When the prevailing direction was mostly at an acute angle with the pivot lateral and blowing in the opposite direction of pivot movement and towards the pivot point (fig. 5, left), absolute EDL were higher than the mean seasonal EDL for spans 5 and 6 of the six-span center pivot (table 3). Wind blowing nearly parallel to the pivot lateral from the end tower towards the pivot point tended to decrease uniformity in irrigation management zones categorized as $Z_{\mathrm{H}-\mathrm{L}}$. However, wind blowing in a direction nearly parallel to the pivot lateral but towards the end tower, tended to have minimal effect on uniformity of application in zones $\mathrm{Z}_{\mathrm{H}-\mathrm{L}}$.

Results were different when the prevailing wind direction was nearly perpendicular to the transect of collectors and moving in the same direction as the center pivot, catch can Trial 3 (fig. 5, right) (fig. 6a). In this trial minimal displacement of irrigation water was observed from one zone to another, except in the case of zone 4 in span 2 which gained water (10\% greater than expected) from zone 3 . This phenomena was likely due to wind gusts or changes in wind direction (table 3). Measured values of $\mathrm{CU}_{\mathrm{HH}}$ and $\mathrm{DU}_{\mathrm{lq}}$ were not substantially affected and remained relatively high ( $\geq 90 \%$ and $>84 \%$, respectively) for collectors in the irrigation management zones and in the grid pattern (fig. 6b).

Evaporation and drift losses for all 15 trials ranged from $1.0 \%$ to $19.0 \%$. These results were similar to the simulated range of losses (7\% to 20\%) reported by Faci et al. (2001) for fixed spray plates at 1 and $2.5 \mathrm{~m}$; and those measured by Ortiz et al. (2009), i.e., 9.2\% and $13.6 \%$ at heights of 1.0 and $2.5 \mathrm{~m}$, respectively, when using fixed spray plates. Playan et al. (2005) observed a mean loss of 9.8\% during daylight hours when operating a conventional linear move with moving spray plate sprinklers spaced $3 \mathrm{~m}$ apart and $2.05 \mathrm{~m}$ above the ground. Mean percent EDL measured from both of our pivots were not significantly different when grouped by span location. However, when grouped by irrigation rate, mean percent EDL increased as application rate increased. Mean percent EDL were negative when measured in zones applying $7.6 \mathrm{~mm}$, indicating that on average there was a gain of water collected in these zones as compared to predicted irrigation depths. Evaporation and drift losses were variable within each irrigation rate; thereby the only significant difference

Table 5. Mean changes in uniformity coefficient, $\Delta C U_{\mathrm{HH}}$, and distribution uniformity, $\Delta D U_{\mathrm{lq}}$, between adjacent management zones (transect-pattern) or sectors (arc-wise pattern) grouped by wind speed. Data were combined from the three- and six-span center pivot systems.

\begin{tabular}{|c|c|c|c|c|c|c|c|c|}
\hline \multirow[b]{3}{*}{ Pattern } & \multirow{3}{*}{$\begin{array}{l}\text { Wind } \\
\text { Scale } \\
\left(\mathrm{m} \mathrm{s}^{-1}\right)\end{array}$} & \multirow{3}{*}{$\begin{array}{l}\text { Affected } \\
\text { Length } \\
\text { (m) }\end{array}$} & \multicolumn{6}{|c|}{$\Delta$ Application Amount ${ }^{[a]}$} \\
\hline & & & \multicolumn{3}{|c|}{$\mathrm{Z}_{\mathrm{L}-\mathrm{H}}$} & \multicolumn{3}{|c|}{$\mathrm{Z}_{\mathrm{H}-\mathrm{L}}$} \\
\hline & & & $\mathrm{N}^{[\mathrm{b}]}$ & $\begin{array}{c}\Delta \mathrm{CU}_{\mathrm{HH}} \\
(\%)\end{array}$ & $\begin{array}{c}\Delta \mathrm{DU}_{\mathrm{lq}} \\
(\%)\end{array}$ & $\mathrm{N}$ & $\begin{array}{c}\Delta \mathrm{CU}_{\mathrm{HH}} \\
(\%)\end{array}$ & $\begin{array}{c}\Delta \mathrm{DU}_{\mathrm{lq}} \\
(\%)\end{array}$ \\
\hline \multirow{8}{*}{ Transect } & \multirow{4}{*}{$U^{[\mathrm{c}]}<5$} & 0 & & $4.2 \mathrm{a}$ & $2.0 \mathrm{a}$ & \multirow{4}{*}{7} & $-6.0 \mathrm{a}$ & $-8.0 \mathrm{a}$ \\
\hline & & 3 & & $3.7 \mathrm{a}$ & $4.0 \mathrm{a}$ & & $-4.0 \mathrm{a}$ & $-3.0 \mathrm{a}$ \\
\hline & & 6 & 4 & $4.2 \mathrm{a}$ & $4.7 \mathrm{a}$ & & $-3.0 \mathrm{a}$ & $-3.0 \mathrm{a}$ \\
\hline & & 9 & & $3.0 \mathrm{a}$ & $3.2 \mathrm{a}$ & & $-2.0 \mathrm{a}$ & $-2.0 \mathrm{a}$ \\
\hline & \multirow{4}{*}{$U>5$} & 0 & \multirow{4}{*}{10} & $8.0 \mathrm{a}$ & $4.5 \mathrm{a}$ & \multirow{4}{*}{7} & $-7.0 \mathrm{a}$ & $-5.0 \mathrm{a}$ \\
\hline & & 3 & & $3.0 \mathrm{a}$ & $4.0 \mathrm{a}$ & & $-4.0 \mathrm{a}$ & $-2.0 \mathrm{a}$ \\
\hline & & 6 & & $2.0 \mathrm{a}$ & $3.0 \mathrm{a}$ & & $-3.0 \mathrm{a}$ & $-1.0 \mathrm{a}$ \\
\hline & & 9 & & $1.0 \mathrm{a}$ & $1.0 \mathrm{a}$ & & $-2.0 \mathrm{a}$ & $-1.0 \mathrm{a}$ \\
\hline \multirow{8}{*}{ Arc-wise } & \multirow{4}{*}{$U<5$} & 0 & \multirow{4}{*}{7} & $6.4 a$ & $4.0 \mathrm{a}$ & \multirow{4}{*}{5} & $-7.0 \mathrm{a}$ & $-4.0 \mathrm{a}$ \\
\hline & & 4 & & $6.6 \mathrm{a}$ & $7.0 \mathrm{a}$ & & $-7.0 \mathrm{a}$ & $-9.0 \mathrm{a}$ \\
\hline & & 7 & & $6.3 \mathrm{a}$ & $5.0 \mathrm{a}$ & & $-6.0 \mathrm{a}$ & $-10.0 \mathrm{a}$ \\
\hline & & 9 & & $5.7 \mathrm{a}$ & $4.0 \mathrm{a}$ & & $-5.0 \mathrm{a}$ & $-6.0 \mathrm{a}$ \\
\hline & \multirow{4}{*}{$U>5$} & 0 & \multirow{4}{*}{3} & $9.7 \mathrm{a}$ & $8.7 \mathrm{a}$ & \multirow{4}{*}{3} & $-6.3 a$ & $-7.0 \mathrm{a}$ \\
\hline & & 4 & & $7.7 \mathrm{a}$ & $7.3 \mathrm{a}$ & & $-5.3 \mathrm{a}$ & $-5.0 \mathrm{a}$ \\
\hline & & 7 & & $5.3 \mathrm{a}$ & $6.7 \mathrm{a}$ & & $-3.7 \mathrm{a}$ & $-7.0 \mathrm{a}$ \\
\hline & & 9 & & $2.7 \mathrm{a}$ & $4.3 \mathrm{a}$ & & $-2.0 \mathrm{a}$ & $-6.0 \mathrm{a}$ \\
\hline
\end{tabular}

[a] Letters of the same value in each column for each pattern and wind group indicate no significant difference.

[b] $\mathrm{N}$ is the number of samples in each category.

[c] $U$ is average wind speed. 
Transect pattern
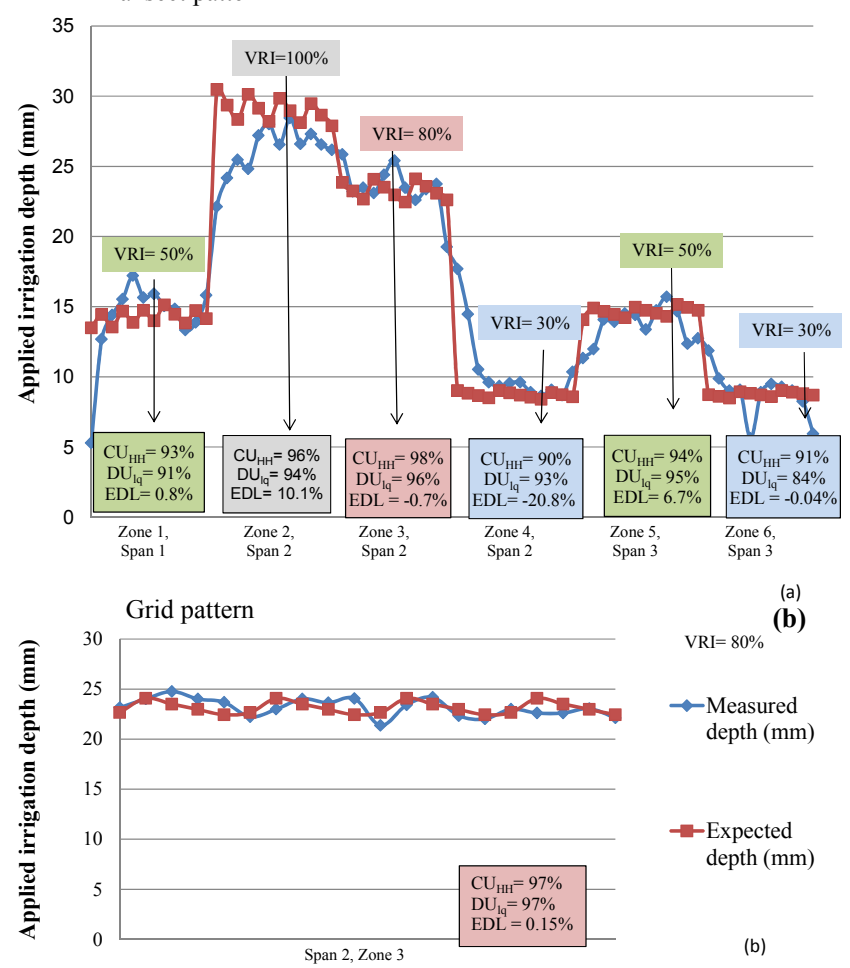

Figure 6. Evaporation and drift losses (EDL), uniformity coefficient $\left(\mathrm{CU}_{\mathrm{HH}}\right)$, distribution uniformity $\left(\mathrm{DU}_{\mathrm{lq}}\right)$, and measured and predicted depths for each zone, Trial 3 (2011) with collectors in: (a) transect and (b) grid pattern.

was between the highest and smallest irrigation rates (table 3). An example of this occurred in Trial 15, when irrigation water drifted from a zone of high irrigation rate $(25 \mathrm{~mm})$ at the end tower towards a zone of a lesser irrigation rate $(12.5 \mathrm{~mm})$ (fig. 7a). This caused drift losses of $20 \%$ in zone 12 , and a gain of $59 \%$ in expected irrigation depth in collectors located in a transect pattern in zone 11. Collectors located in the grid pattern in zone 12 (irrigation rate of $25 \mathrm{~mm}$ ) during this trial, also demonstrated large losses, i.e. $19 \%$ of the predicted amount. Collectors located in the second set of grid patterns (more proximal to the pivot point, Zone 5) experienced 9\% EDL, while irrigating at $7.6 \mathrm{~mm}$ (fig. 7b) during this same trial.

\section{Conclusion}

Multiple catch can tests were performed to test the accuracy of application depth and the uniformity of application of a commercial VRI system for a three- and six-span center pivot irrigation sprinkler. Catch can trials were performed under windy conditions in a location where wind speeds are typically $>5 \mathrm{~m} \mathrm{~s}^{-1}$ for a majority of the year. Accuracy of application depth in the direction of pivot travel ranged from a $\% \mathrm{MBE}$ and $\% \mathrm{RMSE}$ of $3 \%$ to $9 \%$ and $10 \%$ to $16 \%$ for collectors arranged in a grid and arc-wise pattern. Overall, the $\mathrm{CU}_{\mathrm{HH}}>86 \%$ and the $\mathrm{DU}_{\mathrm{lq}}>76 \%$, which was comparable to performances of other VRI systems (linear moves and center pivots), and conventional center pivot systems. These results are important since this study describes a commercial system that is available to
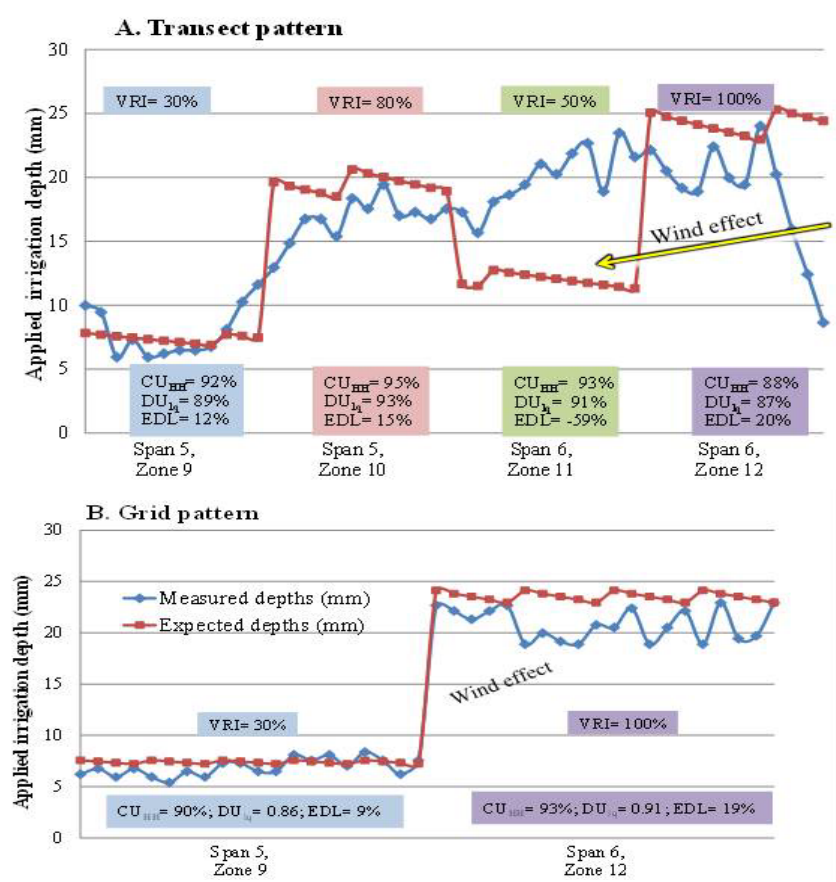

Figure 7. The uniformity coefficient $\left(\mathrm{CU}_{\mathrm{HH}}\right)$, distribution uniformity $\left(D_{\mathrm{lq}}\right)$ and evaporation and drift losses (EDLs) for catch can Trial 15 (2012) for collectors configured in: (A) a transect pattern; and (B) in grid patterns in the outer zones of the six-span center pivot system.

producers, while the other systems reported in the literature with the exception of those used by Dukes and Perry (2006) are not readily available for commercialization. Application uniformity was significantly less in the irrigation management zones where the application depth was $7.6 \mathrm{~mm}$ (pulsing rate $=30 \%$ ). The uniformity of application was significantly affected at the borders of the irrigation management zones along the pivot lateral. The imposed variability was a function of the wetted radius of the sprinklers on the three-span center pivot. In the case of the six-span center pivot system, wind also impacted the width of the variability. The application uniformity measured in an arc-wise direction was typically observed to be of high values $>86 \%$. The catch can analyses did not indicate that uniformity was affected in the direction of pivot travel. Because the $\mathrm{CU}_{\mathrm{HH}}$ and $\mathrm{DU} \mathrm{LQ}_{\mathrm{LQ}}$ were not significantly different in the direction of pivot travel between sectors of differing irrigation rates (arc-wise trials), it is apparent that neither the pulsing mechanism to control the irrigation rates or the speed of valve closure imposed significant variability in the direction of pivot travel.

In general, winds $>5 \mathrm{~m} \mathrm{~s}^{-1}$ increased the uniformity of application within the irrigation management zones of a higher application rate and distal to a zone of a lessor application rate. Reduction of $\mathrm{CU}_{\mathrm{HH}}$ and $\mathrm{DU}_{\mathrm{lq}}$ when wind speeds were $>5 \mathrm{~m} \mathrm{~s}^{-1}$ were observed only when the irrigation rates changed from higher to lower $(\mathrm{H}-\mathrm{L})$ in the zone of the lessor irrigation rate. This reduction was less when the wind direction was inwards towards the pivot point. Wind direction affected the absolute application depth within an irrigation management zone. The MAE, MBE, and RMSE were less than 3.5, 1.9, and $2.9 \mathrm{~mm}$, respectively for each group of data analyzed. Variation in 
expected application depth within a management zone was observed due to wind speed and direction. This could affect site-specific or precision irrigation management.

Future field trials are needed to determine the application uniformity in the VRI system using different system application methods such as low elevation spray (LESA) or low energy precision application (LEPA). Also, additional uniformity testing along spans 1-4 for the sixspan center pivot should be conducted to assess the impact the intermittent movement of the first four towers in the six-span center pivot, since mechanical linkages in the pivot alignment system may produce different results than those measured on the three-span pivot.

\section{ACKNOWLEDGEMENTS}

We gratefully acknowledge support from the USDAARS Ogallala Aquifer Program, a consortium between USDA-Agricultural Research Service, Kansas State University, Texas AgriLife Research, Texas AgriLife Extension Service, Texas Tech University, and West Texas A\&M University. Work reported in this article was accomplished as part of a Cooperative Research and Development Agreement between USDA-ARS and Valmont Industries, Inc., Valley, Nebraska (Agreement No.: 58-3K95-0-1455-M). The dedicated efforts of Mr. Luke Britten, Agricultural Science Research Technician, and Mr. Brice B. Ruthardt, Biological Science Technician, are gratefully acknowledged.

\section{REFERENCES}

ASABE Standards. 2007. S436.1: Test procedure for determining the uniformity of water distribution of center pivot and lateral move irrigation machines equipped with spray or sprinkler nozzles. St. Joseph, Mich.: ASABE.

Christiansen, J. E. 1942. Irrigation by sprinkling. California Agric. Exp. Station. Bulletin No. 570. Berkeley, Calif.: Univ. of Calif.:

Chavez, J. L., F. J. Pierce, T. V. Elliott, R. G. Evans, Y. Kim, and W. M. Iversen. 2010. A remote irrigation monitoring and control system (RIMCS) for continuous move systems. Part B: field testing and results. Prec. Agric. 11(1): 11-26.

Clark, G. A., K. Srinivas, D. H. Rogers, R. Stratton, and V. L. Martin. 2003. Measured and simulated uniformity of Low Drift Nozzle sprinklers. Trans. ASAE 46(2): 321-330.

Dogan, E., H. Kirnak, and Z. Dogan. 2008. Effect of varying the distance of collectors below a sprinkler head and travel speed on measurements of mean water depth and uniformity for a linear move irrigation sprinkler system. Biosys Engr. 99(2): 190-195.

Dukes, M. D., and C. Perry. 2006. Uniformity testing of a variablerate center pivot irrigation control systems. Precision Agric. 7(3): 205-218.

Evans, R. G., S. Han, M. W. Kroeger, and S. M. Schneider. 1996.Precision center pivot irrigation for efficient use of water and nitrogen. In Proc. 3rd Intl. Conf. on Precision Agriculture, 75-84. P. C. Robert, R. H. Rust, and W. E. Larsen, eds. Madison, Wis.: ASA

Evett, S. R., W. P. Kustas, P. H. Gowda, J. H. Prueger, and T. A. Howell. 2011. Overview of the Bushland Evapotranspiration and Agricultural Remote sensing Experiment 2008 (BEAREX08): A field experiment evaluating methods quantifying ET at multiple scales. Advances in Water Resources 50: 4-19.
Faci, J. M., R. Salvador, and E. Playan. 2001. Comparison of fixed and rotating spray plate sprinklers. J. Irrig. Drainage Engr. 127(4): 224-233.

Frost, K. R. and H. C. Schwalen. 1955. Sprinkler evaporation losses. Agricultural Engineering 36(8): 526-528.

Han, Y. J., A. Khalilian, T. W. Owino, H. J. Farahani, and S. Moore. 2009. Development of Clemson variable-rate lateral irrigation system. Computers and Electronics in Agric. 68(1): 108-113.

Hanson, B. R., and S. B. Orloff. 1996. Rotator nozzles more uniform than spray nozzles on center-pivot sprinklers. California Agric. 50(1): 32-35.

Heermann, D. F., and P. R. Hein. 1968. Performance characteristics of self-propelled center-pivot sprinkler machines. Trans. ASAE 11(1): 11-15.

Hills, D. J., and J. Barragan. 1998. Application Uniformity for fixed and rotating spray plate sprinklers. Applied Eng. in Agric. 14(1): 33-36.

Keuls, M. 1952. The use of the "studentized range" in connection with an analysis of variance. Euphytica 1(2): 112-122.

Kincaid, D. C., K. H. Solomon, and J. C. Oliphant. 1996. Drop size distribution for irrigation sprinklers. Trans. ASAE 39(3): 839845.

King, B. A., and R.W. Wall. 1998. Supervisory control and data acquisition system for site-specific center pivot irrigation. Applied Eng. in Agric. 14(2): 135-144.

King, B. A., I. R. McCann, C. V. Eberlein, and J. C. Stark. 1999. Computer control system for spatially varied water and chemical application studies with continuous-move irrigation systems. Computers and Electronics in Agric. 24(3): 177-194.

King, B. A., and D. C. Kincaid. 2004. A variable flow rate sprinkler for site-specific irrigation management. Trans. ASAE. 20(6): 765-770.

King, B.A., R.W. Wall, D.C. Kincaid, and D.T. Westermann. 2005. Field testing of a variable rate sprinkler and control system for site-specific water and nutrient application. Applied Eng. in Agric. 21(5): 847-853.

Kohl, R. A. 1972. Sprinkler precipitation gage errors. Trans. ASAE 15(2): 264-265, 271.

Kruse, E. G. 1978. Describing irrigation efficiency and uniformity. ASCE J. Irrig. and Drain. Div. 104(1): 35-41.

Kruskal, W., and A. Wallis. 1952. Use of ranks in one-criterion variance analysis. J. Am. Stat. Assoc. 47(260): 583-621.

Marek, T. H., A. D. Schneider, S. N. Baker, and T. W. Popham. 1985. Accuracy of three sprinkler collectors. Trans. ASAE 28(4): 1191-1195.

Merriam, J.L. and J. Keller. 1978. Farm Irrigation System Evaluation: A Guide for Management. Logan, Utah: Utah State Univ.

McCann, I. R., B. A. King, and J. C. Stark. 1997. Variable rate water and chemical application for continuous-move sprinkler irrigation systems. Applied Eng. in Agric. 13(5): 609-615.

Newman, D. 1939. The distribution of range in samples from a normal population, expressed in terms of an independent estimate of standard deviation. Biometrika. 31(1): 20-30. DOI:10.1093/biomet/31.1-2.20.

Omary, M., C. R. Camp, and E. J. Sadler. 1997. Center pivot irrigation system modification to provide variable water application depths. Applied Eng.in Aric. 13(2): 235-239.

Ortiz, J. N., J. M. Tarjuelo, and J. A. de Juan. 2009. Characterization of evaporation and drift losses with centre pivots. Agric. Water Manage. 96(11): 1541-1546.

Ortiz, J. N., J. A. de Juan, and J. M. Tarjuelo. 2010. Analysis of water application uniformity form a centre pivot irrigator and its effect on sugar beet (Beta vulgaris L.) yield. Biosys Engr. 105(3): 367-379. 
Playán, E., R. Salvador, J.M. Faci, N. Zapata, A. Martínez-Cob, and I. Sánchez. 2005. Day and night wind drift and evaporation losses in sprinkler solid-sets and moving laterals. Agric. Water Manage. 76(3): 139-159.

Playán, E., N. Zapata, J. M. Faci, D. Tolosa, J. L. Lacueva, J. Pelegrín, R. Salvador, I. Sánchez, and A. Afita. 2006. Assessing sprinkler irrigation uniformity using a ballistic simulation model. Agric. Water Manage. 84(1-2): 89-100.

Rogers, D.H., M. Alam, L.K. Shaw, and G.A. Clark. 2009. Impact of collector size and spacing on center pivot uniformity evaluations. ASABE Paper No. 09-6522. St. Joseph, Mich: ASABE.

Sadler, E. J., C. R. Camp, D. E. Evans, and L. J. Ursey. 1996. A sitespecific center pivot irrigation system for highly-variable coastal plain soils. In Proc. 3rd Intl. Conf. on Precision Agriculture, eds. P. C. Robert, R. H. Rust, and W. E. Larsen, 827-834. Madison, Wis.: ASA.

Seginer, I., and M. Kostrinsky.1975.Wind, sprinkler patterns, and system design. J. Irrig. Drainage Division, Proc. of ASCE 101(IR4): 251-264.

Seginer, I., D. Kantz, and D. Nir. 1991. Wind-distorted singlesprinkler distribution patterns. Agric. Water Manage.19(4): 341359.
Shapiro, S. S., and B. Wilk. 1965. An analysis of variance test for normality (complete samples). Biometrika 52(3-4): 591-611.

Solomon, K. H., D. C. Kincaid, and J. C. Bezdek. 1985. Drop size distributions for irrigation spray nozzles. Trans. ASAE 28(6): 1966-1974

Steiner, J. L., E. T. Kanemasu, and R. N. Clark. 1983. Spray losses and partitioning of water under a center pivot sprinkler system. Trans. ASAE 26(4): 1128-1134.

Stone, K. C., E. J. Sadler, J. A. Millen, D. E. Evans, and C. R. Camp. 2006. Water flow rates from a site-specific irrigation system. Appl. Eng. in Agric. 22(1): 73-78.

Tarjuelo, J. M., J. Montero, M. Valiente, F. Honrubia, and J. Ortiz. 1999. Irrigation uniformity with medium size sprinklers. Part II. Influence of wind and other factors on water distribution. Trans. ASAE 42(3): 677-689.

U.S. Department of Agriculture (USDA), National Agricultural Statistics Service (NASS). 2009. 2008 Farm and Ranch Irrigation Survey. Washington, DC: USDA-NASS.

Zhang, L., G. P. Merkley, and K. Pinthong. 2011. Assessing wholefield sprinkler irrigation application uniformity. Irri. Sci. DOI 10.1007/s00271-011-0294-0. 